\title{
A systematic assessment of 'Axial Age' proposals using global comparative historical evidence
}

Daniel Austin Mullins* ${ }^{1}$, Daniel Hoyer*2,6 ${ }^{2}$ Christina Collins ${ }^{3}$, Thomas Currie ${ }^{3}$, Kevin Feeney ${ }^{4}$, Pieter François ${ }^{1}$, Patrick E. Savage ${ }^{1,7}$, Harvey Whitehouse ${ }^{1}$, Peter Turchin ${ }^{5,6}$

${ }^{1}$ University of Oxford

${ }^{2}$ University of Toronto

${ }^{3}$ University of Exeter

${ }^{4}$ Trinity College Dublin

${ }^{5}$ University of Connecticut

${ }^{6}$ Evolution Institute

${ }^{7}$ Keio University SFC

Proponents of the Axial Age contend that parallel cultural developments between 800 and 200 BCE in what is today China, Greece, India, Iran, and Israel-Palestine constitute the global historical turning point towards modernity. While the Axial Age concept is well-known and influential, deficiencies in the historical evidence and sociological analysis available have thwarted efforts to evaluate the Axial Age concept's major global contentions. As a result, the Axial Age concept remains controversial. Seshat: Global History Databank provides new tools for examining this topic in social formations across Afro-Eurasia during the first two millennia BCE and first millennium CE, allowing scholars to empirically evaluate the many variedand contrasting - claims put forward about this period. Our systematic investigation undercuts the notion of a specific 'age' of axiality limited to a specific geo-temporal localization. Critical traits offered as evidence of an axial transformation by proponents of the Axial Age concept are shown to have appeared across Afro-Eurasia hundreds and in some cases thousands of years prior to the proposed Axial Age. Our analysis raises important questions for future evaluations of this period and points the way towards empirically-led, historical-sociological investigations of the ideological and institutional foundations of complex societies. 
Acknowledgements: Daniel Austin Mullins and Daniel Hoyer contributed equally in leading the design, analysis, and writing of this article. We gratefully acknowledge the contributions of our team of research assistants, post-doctoral researchers, consultants, and experts. See www.seshatdatabank.info for a comprehensive list of donors, partners, experts, and consultants. A workshop, Testing the Axial Age, was held at the University of Oxford in January 2017. The present paper benefited enormously from the generous and engaging discussions held there with invited historians and archaeologists specializing in different areas related to the Axial Age concept. In attendance were Profs. John Baines (Oxford), Julye Bidmead (Chapman), Robin Coningham (Durham), Jennifer Larson (Kent State), Barend ter Haar (Oxford), and Vesna Wallace (UC Santa Barbara). Many of the comments and insights expressed at the workshop are cited in the article as personal communications. We also wish to acknowledge the incredible hard work of Seshat's Research Assistants, namely Eva Brandl, Enrico Cioni, Agathe Dupeyron, Greine Jordan, Jill Levine, Jenny Reddish, and Edward Turner.

Grant Information: This work was supported by a John Templeton Foundation grant to the Evolution Institute, entitled "Axial-Age Religions and the Z-Curve of Human Egalitarianism," a Tricoastal Foundation grant to the Evolution Institute, entitled "The Deep Roots of the Modern World: The Cultural Evolution of Economic Growth and Political Stability," an ESRC Large Grant, entitled "Ritual, Community, and Conflict" (REF RES-060-25-0085), an Advanced Grant from the European Research Council (ERC) under the European Union's Horizon 2020 Research and Innovation Programme (grant agreement No. 694986), an award from the Templeton World Charity Foundation entitled "Cognitive and Cultural Foundations of Religion and Morality", and a grant from the European Union Horizon 2020 research and innovation programme (grant agreement No 644055 [ALIGNED, www.aligned-project.eu]).

Keywords: Comparative/historical sociology, Ethics, Religion, Social change, Modernity

Corresponding Author: Dr Daniel Austin Mullins, 64 Banbury Road, Oxford, OX2 6PN, +44 7842 069457, daniel.mullins@anthro.ox.ac.uk

Words including text, references, and footnotes (excluding tables and figures): 14,357 
Daniel Austin Mullins is Research Associate in the School of Anthropology and Museum Ethnography at the University of Oxford and Postdoctoral Research Associate on the Seshat: Global History Databank. His research lies at the intersection of anthropology, macrohistory, sociology, and archaeology. He is interested in understanding how cooperative groups emerge and evolve, and what role morality, literacy, and ritual play in this. His current work draws on comparative historical data and evolutionary theory to investigate why human groups became more prosocial and egalitarian. He earned his DPhil as a Clarendon Scholar from the University of Oxford.

Daniel Hoyer is Project Manager of Seshat: Global History Databank and Visiting Scholar at the University of Toronto. He holds a PhD in Classics from New York University, where he studied economic and social development in the high Roman Empire. His current research employs comparative historical and social scientific methods to explore the causes and limiting factors to economic growth, societal development, and general well-being. In particular, he is interested in understanding the role of prosocial cultural traits in promoting equitable distribution of resources and limiting predatory activity in past societies.

Christina Collins is an Associate Research Assistant at the University of Exeter, College of Life and Environmental Sciences. She holds a PhD in prehistoric demography from the University of Sheffield. Her current research interests include ancient demography, early agriculture, and archaeological mapping. She is particularly interested in developing new methods in archaeological analysis.

Thomas Currie is a Senior Lecturer in Cultural Evolution and member of the Human Biological and Cultural Evolution Group in the Centre for Ecology \& Conservation at the University of Exeter. His research focuses on investigating human behavior and cultural diversity using evolutionary theory. He uses quantitative techniques to test competing hypotheses about how and why cultural traits and societies change over time, and to understand what ecological and social factors drive the evolution of social and political organization. He is a member of the board of directors of Seshat: Global History Databank.

Kevin Feeney is a senior research fellow in the School of Computer Science and Statistics, Trinity College Dublin, the Information Technology Editor and founding member of Seshat: Global History Databank, project leader of the DACURA Database Curation and management system, and leader of the $€ 4$ million pan-European ALIGNED research project. His research focuses on developing technological systems which allow human organisations to turn data into actionable knowledge. He has published over 50 peer-reviewed papers in leading high-impact international journals and conferences such as IEEE Internet Computing, Elsevier's Computer Networks and the Semantic Web Journal.

Pieter François is the Fellow of Anthropology at St. Benet's, University of Oxford. He is also the Research Coordinator of the Cultural Evolution Lab at the Centre for Anthropology and Mind, University of Oxford. He is a Founding Director and the Historical Coordinator of Seshat: Global History Databank. His work focuses on the evolution of social complexity, social cohesion, and ritual and religious behaviour. He has also published extensively on Digital Humanities and Big Data methodologies.

Patrick E. Savage is Postdoctoral Researcher in the School of Anthropology and Museum Ethnography at the University of Oxford. He is also Special Associate Professor in the Faculty of Environment and Information Studies at Keio University SFC (Shonan Fujisawa Campus). He 
earned his $\mathrm{PhD}$ in Musicology from the Tokyo University of the Arts. His research focuses on the evolution of ritual, religion, and the arts, and their broader relationship with society.

Harvey Whitehouse is Professor in the School of Anthropology and Museum Ethnography and Director of the Institute of Cognitive and Evolutionary Anthropology at the University of Oxford. He is Founding Director of Seshat: Global History Databank and editor of the ritual emotionality of rituals determines the scale and structure of many social groups. His books include Inside the Cult (1995), Arguments and Icons (2000) and Modes of Religiosity (2004).

Peter Turchin is Professor in the Department of Ecology and Evolutionary Biology at the University of Connecticut; External Faculty at the Complexity Science Hub, Vienna; and Research Associate in the School of Anthropology, University of Oxford. He is a Founding Director and the Overall Coordinator of Seshat: Global History Databank and editor of the War and Peace and War (2005), Secular Cycles (2009), and most recently Ultrasociety (2016) and Ages of Discord (2016). 
The 'Axial Age' refers to a historical period in the mid-first millennium BCE during which a cluster of changes in cultural traditions are said to have occurred in some of the complex social formations in what is today China, Greece, India, Iran, and the area that is today Israel-Palestine. This period is said to have witnessed a transformation in the relationship between rulers and ruled and laws and customs together with the emergence of a new form of moralising religion and ideology, as manifested in Buddhism, Confucianism, Hinduism, Judaism, Platonism, and Zoroastrianism. Much Axial Age scholarship attempts to characterize these changes, starting with the argument that numerous major religious figures promoting similar moralizing and equity-promoting ideologies emerged at roughly the same time in a handful of arguably disconnected societies, ultimately morphing into some of the world's most widespread ideologies. For example, Christianity, Islam, and Buddhism all trace their roots to this period.

The importance of these ideologies and some of the innovations characteristic of the period, not only for the past societies in which they occurred but also for their impact on the modern world, has made the idea of an Axial Age an attractive one for many scholars and commentators for the last half-century. The Axial Age, however, has been developed over many years and espoused by numerous scholars, each adding their own element to the concept. The basic argument that there was an Axial Age has, over so many iterations, been explained and defined in a wide variety of ways, with different scholars focusing on different temporal, geographic, and thematic claims. Further, there has been very little large-scale, wide-ranging investigation of the many ideas espoused by this literature - particularly regarding the temporal and geographic range as well as causal factors - while the analytic work that has been done relies on a very limited range of empirical, historical evidence. As a result, many key questions surrounding this interesting and important concept are in need of evidence-based, systematic exploration.

Though the observation has been made for over a century (cf. Weber 1978 [1922]), recent highprofile discussions surrounding the Axial Age have put this alluring notion back on the agenda in disciplines across the social sciences, including sociology (e.g., Bellah 2011, Bellah and Joas 2012), anthropology (e.g., Atran 2016), psychology (e.g., Boyer and Baumard 2016, Norenzayan et al. 2016), philosophy (e.g., Habermas 2010), economic history (e.g., Morris 2010), and cultural evolution (e.g., Turchin 2015). While the sociology of morality is a topic of renewed concern generally (Lizardo 2016, Stets and Carter 2012), the proposed transformative impact of the Axial Age on ideas of morality remain poorly understood. In evaluating previous work on the topic, it is clear that it has brought invaluable insights into the innovations that led to some of the most important and influential ancient ideologies (Buddhism, Confucianism, Platonic philosophy, etc.). However, the precise circumstances that led to these breakthroughs-how and why these novel ideas took off and spread, when and where they originated, why they didn't happen elsewhere or at other times, and a host of similar questions-have never been fully articulated. Largely, we argue, this is due to the immense scope of the Axial Age concept, which concerns all societies across Afro-Eurasia (and ultimately the rest of the world) and deals with sociocultural dynamics spanning thousands of years. To offer a truly comprehensive and systematic investigation of the key issues at stake would require combining the enormous wealth of historical and theoretical material available across numerous sub-disciplines and scholarly traditions. A prohibitive endeavor for any individual scholar.

Fortunately, the emerging field of Cliodynamics offers an effective methodology for tackling exactly these sorts of large-scale, macro-historical 'big questions' (Turchin 2008, Turchin 2011). We built a new resource for large-scale historical-sociological research inspired by the Cliodynamic approach: the Seshat: Global History Databank (Turchin et al 2012; Turchin et al 
2015; François et al 2016). The Seshat Databank has collected structured historical evidence concerning the key ideas expressed by influential scholars writing about the Axial Age, covering societies across Afro-Eurasia stretching from the Neolithic to the early modern period. Seshat's broad temporal coverage and geographic range ${ }^{1}$ provides unique advantages towards conducting an empirically-informed, systematic socio-historical investigation of the Axial Age and its various conceptualizations. We take a macro-level view of the topic, seeking to clarify the various proposals that proponents of the Axial Age idea have made over the years and to offer new answers to some of the lingering questions raised by this diverse body of scholarship. We bring a novel approach, offering a systematic exploration of these key ideas and themes and then assessing major predictions against a large body of empirical, historical evidence. Our approach offers two principal advantages over previous work: 1) we take a much longer time-frame, which allows us to track the dynamics of how the various 'axial' ideas grew and spread over time; and 2) we draw material not only from the handful of regions typically noted as being centers of 'axiality', but also include supposedly non-axial areas to assess the allegedly unique contribution of the different thinkers, societies, and ideas noted by Axial Age scholars.

We begin this article by surveying the intellectual history of scholarship concerning the Axial Age and discussing the foundations underlying the recent renewed interest in this topic. We survey - and attempt to synthesize - the diverse, though closely linked, claims that have been made by supporters of the Axial Age. We proceed to outline the major lingering questions and interpretive issues posed by this scholarship. We then detail our assessment of empirical historical evidence drawn from a large sample of past societies across Afro-Eurasia, outlining the context in which the thinkers who promoted 'axial'-type ideologies first emerged in different parts of the world and tracing the dynamic spread of these ideas to nearly every corner of the globe. Our investigation allows us to answer many of the critical open questions surrounding the Axial Age, honing in on what remains compelling about the concept, while also raising many new questions. In the final section, we highlight some interesting new topics of comparative historical-sociological enquiry arising out of our assessment and their implications for our understanding of the ideological and institutional foundations of complex societies.

\section{INTELLECTUAL HISTORY OF THE AXIAL AGE}

Across several comparative essays on world religions, Max Weber noted that, during the first millennium BCE, several potentially important parallels between thought and spirituality developed in the great world empires found in present-day China, Greece, India, Iran, and Israel (Weber 1978 [1922]:441) ${ }^{2}$. He did not develop this speculation further, however, because of the "scant knowledge" available at the time. Several others have picked up the charge in the decades that followed, arguing that these parallel developments in thought and spirituality are evidence of an important transition towards modernization.

This period of transition has been variously described as the 'Moral Revolution' (Stuart-Glennie 1873), the 'prophetic age' (Weber 1978[1922]), 'die Achsenzeit' (literally 'the axis time', translated as 'the Axial Age'; (Jaspers 1953[1943]), the 'Ecumenic Age' (Voegelin 1974), the 'age of transcendence' (Schwartz 1975), 'an age of criticism' (Momigliano 1975), and more recently as a 'revolution in worldviews' (Habermas 2010) and 'the Great Transformation' (Armstrong 2006). Of these descriptors, the concept of 'the Axial Age' by Karl Jaspers (1949, 1953) has attracted the most scholastic attention. 
Jaspers (1948:430) provided the initial and still dominant formulation of the Axial Age in the aftermath of the Second World War in an attempt to salvage what he called the "spirit of Europe" in the midst of post-war devastation. Jaspers set out to develop a universal history to identify the roots of modernity across Eurasia, ultimately arguing that significant communalities across world regions between 800 and $200 \mathrm{BCE}$ indicate that a singular, epochal, and unprecedented shift in cultural systems occurred during this time-period. Most subsequent proponents of the Axial Age (e.g., Armstrong 2006, Eisenstadt 1986, Hick 2004, Momigliano 1975, Schwartz 1975, Taylor 2009, Voegelin 1974) have followed Jaspers' basic formulation, with differences largely revolving around who is considered a proper 'axial' thinker, be it Confucius, Plato, Buddha, Mani, Zoroaster (Zarathustra), etc., or the extent to which particular ideologies should be described as a true 'breakthrough' and, thus, which social formations, religions, or philosophies belong to the age.

Several prominent scholars have taken up and expanded Jaspers' concept, recounting the period's major breakthroughs in the way that people thought critically about their roles and responsibilities in society as well as their relationships with their those in power-elites, rulers, and the divine. Notably, across many high-profile publications, both Eisenstadt (1986, 1996, 2005, 2011) and Bellah $(2005,2011,2012)$ refine the idea of the Axial Age, highlighting the major developments in socio-political institutions and stressing the cognitive or intellectual changes underpinning these key 'axial' transformations. Eisenstadt first added a more tangible, political dimension to Jaspers' conception, arguing that the goals of individuals during this age shifted from maintaining to transforming socio-political order, leading to the creation of new institutions for legitimating authority and redefining existing orthodoxy as well as orthopraxy in religious, political, and cultural arenas. Bellah, whose ideas have been particularly resonant in recent years, followed Donald's (1991) typology of cultural change in distinguishing four stages of human consciousness (episodic, mythic, mimetic and theoretic) when theorizing about the Axial Age (2011), with the final stage being when individuals adopt 'second order thinking', take on a rational and universalist worldview, and employ written language (at least amongst elites). By this conception, the Axial Age marks the major leap in cultural evolution when humans undertook the cognitive transition from the mimetic to the theoretic stage. Both Eisenstadt and Bellah considered the emergence of 'second order thinking' or 'theoretic culture' to be the chief causal factor of the Axial Age, the great transformation that led, slowly but surely, to the cultural, social, and political changes that characterize a society's transition from something 'archaic' to something decidedly 'modern' (Arnason et al. 2005; Bellah 2011).

Baumard and colleagues follow this line too, noting a major cognitive change as the defining characteristic of axiality (Baumard and Boyer 2013, Baumard, Hyafil and Boyer 2015, Baumard et al. 2015). Citing Life-History Theory (see Fabian and Flatt 2012), they argue that the Axial Age was characterized by a change in short-term to long-term cognitive orientations. ${ }^{3}$ Neverbefore-achieved levels of affluence afforded to elites during this period prompted them to alter their behavioral goals towards more long-term oriented behaviors, which Baumard and colleagues associate with increases in cooperative behaviors, sustainable consumption patterns, and ultimately the self-discipline and asceticism of nascent moralizing religions. By focusing on the behavioral response to a cognitive shift resulting from material circumstances, Baumard and colleagues join a long line of scholars who argued that cognitive and intellectual development was the 'first mover' of the Axial Age.

Interestingly, the Axial Age concept has enjoyed a surge in popularity in recent years, both by scholars from various disciplines as well as religious leaders, political reformers, and the media. ${ }^{4}$ 
Recent proponents of the Axial Age concept largely reiterate Jaspers' initial objective of tracing commonalities between contemporary societies. For Jaspers, this common origin provided a sense of original unity that could be used to build solidarity between diverse groups and forestall potential conflict. Recent commentators have embraced the idea that we are currently living through a second Axial Age; a renewed period of transformation that may serve to foster a renewed sense of trans-national collaboration and ideological cross-fertilization. This recent engagement with the Axial Age(s) lends some immediacy to our project here, as we attempt to clarify, assess, and answer lingering questions about this important, yet opaque concept. Before explicating the central unresolved issues about the Axial Age, we turn now to outline how the various scholars who have written on the topic have sought to answer the fundamental questions, what, exactly, is the Axial Age?

\section{KEY CONJECTURES ABOUT THE ONSET, EXTENT, AND SPREAD OF THE AXIAL AGE}

The variety of Axial Age postulates can be seen clearly in Table 1. By and large, prominent Axial Age predictions relate to one of two basic topics: 1) the cultural transformations associated with the Axial Age (whenever/wherever it is placed) and their legacy, and 2) the factors that either facilitated axiality or impeded axiality. Table 1 illustrates this, demonstrating not only the variety of predictions associated with the Axial Age's cultural transformations, but the equally wide array of factors that have been offered to explain why these transformations did or did not occur.

Despite their wide variability, nearly all arguments about the Axial Age share a commitment to several inter-related core conjectures. First, nearly all proponents of the Axial Age argue that new ideologies stressing universalizing moral religio-philosophical principles emerged initially and exclusively in a handful of regions across Afro-Eurasia during the mid-first millennium $\mathrm{BCE}$; and that, thus, these innovations did not occur before or elsewhere. Second, they contend that these ideologies led to radical reforms of the social, cultural, and political institutions of the societies to which they spread, including a more equitable and 'secularized' application of legal rights and responsibilities, reductions in the degree of arbitrary power claimed by rulers, changes in the way rulers legitimated their authority especially vis-à-vis the divine, and in the force of ideological and normative emphasis on prosocial ${ }^{5}$ behavior. Finally, many scholars who work on the Axial Age contend that these ideologies and the sociocultural developments they spawned have had a transformative and persistent influence on nearly all subsequent societies around the globe.

Moreover, proponents of the Axial Age concept typically base their claims about the existence and nature of an Axial Age around four central hypotheses: 1) there was a historically discrete Axial 'Age' or period, 2) axial transformations occurred in a handful of geographically circumscribed regions, but eventually spread across the globe, 3) historical inquiry should focus on the activities of a handful of seemingly extraordinary individuals, and 4) axial transformations arose out of major cognitive and intellectual developments that produced radical questioning and introspection concerning the relationships between rulers and ruled as well as the role-and application of - legal institutions. We now briefly discuss each of these 4 principal suppositions in turn, highlighting prominent and common claims as well as pointing out areas of disagreement. 
Table 1. Overview of claims made in prominent works on the Axial Age

\begin{tabular}{|c|c|c|c|}
\hline \multicolumn{2}{|c|}{$\begin{array}{l}\text { Cultural transformation associated } \\
\text { with axiality and their legacy }\end{array}$} & \multicolumn{2}{|c|}{$\begin{array}{l}\text { Factors that facilitated or } \\
\text { impeded axiality }\end{array}$} \\
\hline $\begin{array}{c}\text { Temporally / spatially } \\
\text { delimited transformations }\end{array}$ & Historical legacy & $\begin{array}{c}\text { Factors that facilitated } \\
\text { axiality }\end{array}$ & $\begin{array}{c}\text { Factors that } \\
\text { impeded axiality }\end{array}$ \\
\hline $\begin{array}{l}\text { Emergence of universalizing } \\
\text { moralizing } \\
\text { religious/philosophical } \\
\text { traditions (Baumard and } \\
\text { Boyer 2013, Baumard, } \\
\text { Hyafil and Boyer 2015, } \\
\text { Baumard et al. 2015, } \\
\text { Eisenstadt 2005, Jaspers } \\
\text { 1953:3, Mumford 1956) } \\
\text { Emergence of a universal } \\
\text { egalitarian ethic (Bellah } \\
2011: 573 \text { ) } \\
\text { Emergence of a doctrinal } \\
\text { tension between the } \\
\text { transcendental and mundane } \\
\text { orders amongst elites } \\
\text { (Eisenstadt 1986, Jaspers } \\
\text { 1953, Taylor 2009:39, } \\
\text { Voegelin 1974) }\end{array}$ & $\begin{array}{l}\text { Modern 'world } \\
\text { religions', including } \\
\text { Buddhism, Jainism, } \\
\text { Hinduism, Daoism, } \\
\text { Judaism, Christianity, } \\
\text { and Islam (Baumard } \\
\text { and Boyer 2013, } \\
\text { Baumard, Hyafil and } \\
\text { Boyer 2015, Baumard } \\
\text { et al. 2015, Bellah } \\
\text { 2011, Cobb 1979, } \\
\text { Jaspers 1953, } \\
\text { Wittrock 2012:102) } \\
\text { The legitimacy of } \\
\text { ruling elite and the } \\
\text { rituals of the official } \\
\text { cult are challenged } \\
\text { (Bellah 2011:571) } \\
\text { Religio-philosophical } \\
\text { traditions promoting } \\
\text { the idea of individual } \\
\text { accountability } \\
\text { (Jaspers 1953) } \\
\text { Religio-philosophical } \\
\text { traditions promoting } \\
\text { the idea of } \\
\text { salvation/redemption/1 } \\
\text { iberation (Jaspers } \\
\text { 1953) } \\
\text { Cognitive capacity } \\
\text { and predilection for } \\
\text { critical evaluation of } \\
\text { existing power } \\
\text { structures, institutions, } \\
\text { and normative tenets, } \\
\text { including religio- } \\
\text { philosophical texts } \\
\text { (Bellah 2011:281-83) }\end{array}$ & $\begin{array}{l}\text { Increased socio-political } \\
\text { complexity in the small } \\
\text { urban states, not empires } \\
\text { (Bellah 2005, Bellah } \\
\text { 2011, Jaspers 1953, } \\
\text { Momigliano 1975:8-9). } \\
\text { N.B.: Baumard et al. } \\
\text { (2015) contest this } \\
\text { association. } \\
\text { Increased } \\
\text { cosmopolitanism } \\
\text { (Jaspers 1953:4) } \\
\text { Increased affluence } \\
\text { amongst elites (Baumard } \\
\text { et al. 2015, Jaspers } \\
\text { 1953:4) } \\
\text { Increased energy capture } \\
\text { (kcal per capita per day) } \\
\text { (Baumard et al. 2015) } \\
\text { Increased presence of } \\
\text { writing and } \\
\text { recordkeeping } \\
\text { technologies (Bellah } \\
\text { 2005, Bellah 2011, } \\
\text { Mumford 1956). N.B.: } \\
\text { Baumard et al. (2015) } \\
\text { contest this prediction. } \\
\text { Increased warfare/inter- } \\
\text { civilizational conflict, } \\
\text { including the large-scale } \\
\text { territorial expansion of } \\
\text { Central Asian equestrian } \\
\text { peoples into China, India } \\
\text { and the West ((Jaspers } \\
\text { 1953:16-17), the spread } \\
\text { of iron weapons and } \\
\text { armor (Bellah 2011:269), } \\
\text { or a combination of these } \\
\text { two factors (Turchin } \\
\text { 2012, Turchin 2015). }\end{array}$ & $\begin{array}{l}\text { Loss of 'dynamism' } \\
\text { for axial } \\
\text { transformations } \\
\text { over time; } \\
\text { resiliency of pre- } \\
\text { axial socio- } \\
\text { political forms } \\
\text { (Jaspers 1953) } \\
\text { Low growth in } \\
\text { affluence, difficult } \\
\text { relations among } \\
\text { social classes } \\
\text { (Baumard et al. } \\
\text { 2015) } \\
\text { Lack of } \\
\text { evolutionary } \\
\text { pressure to develop } \\
\text { cooperation- } \\
\text { promoting norms } \\
\text { and institutions } \\
\text { where inter- } \\
\text { societal } \\
\text { competition was } \\
\text { weak (Turchin } \\
\text { 2012) }\end{array}$ \\
\hline
\end{tabular}




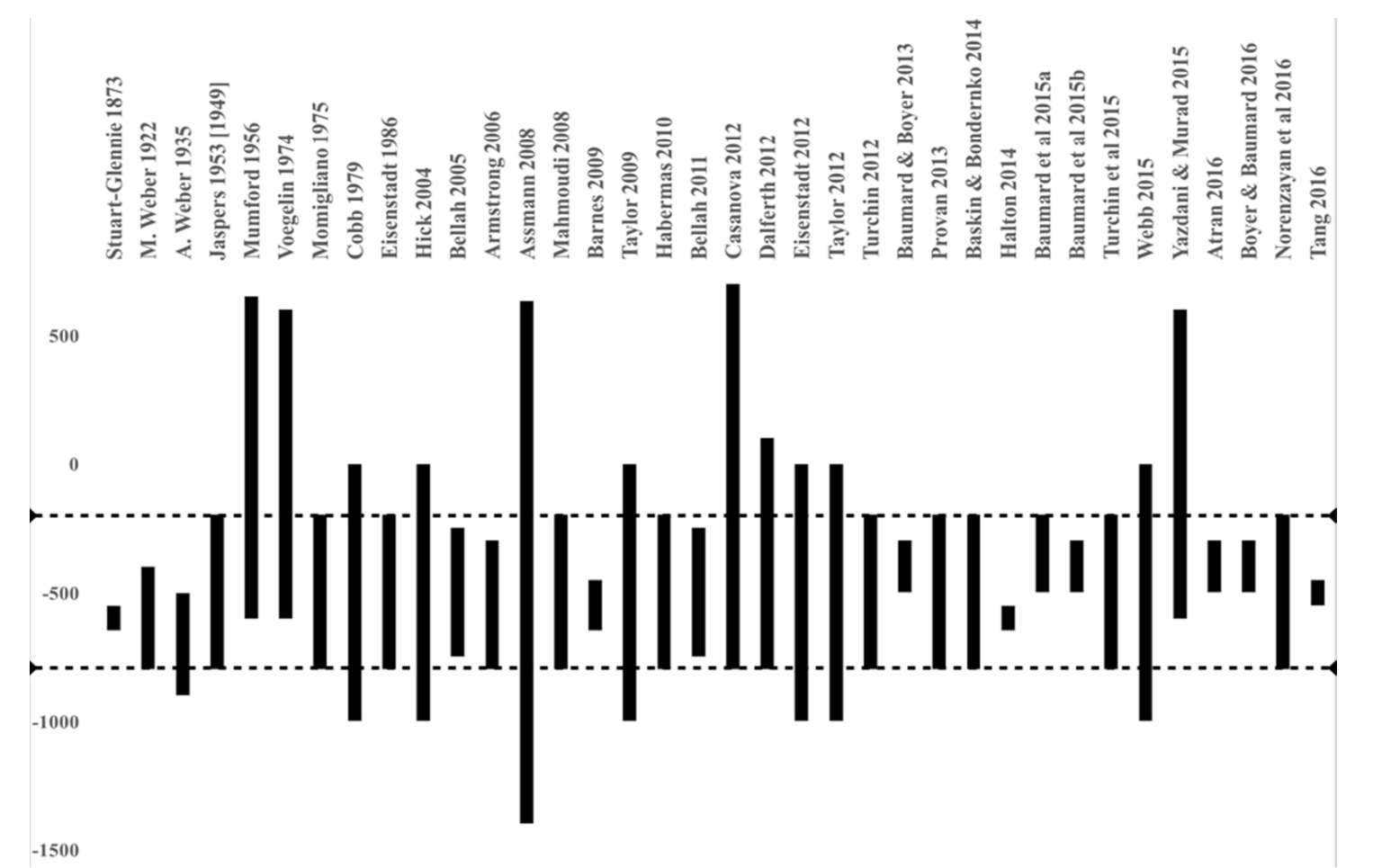

\begin{abstract}
Figure 1. Vertical lines indicate the time-periods assigned to the Axial Age, as identified in prominent publications on the topic. Broken horizontal lines indicate mean start (770 BCE) and end (110 BCE) times for the Axial Age, which align with Jaspers' original conception of the period as stretching from 800-200 BCE.
\end{abstract}

According to Jaspers (1953), the crucial tipping point of history transpired "around $500 \mathrm{BC}$, in the spiritual process that occurred between 800 and 200 BC." Jaspers (1953)argued that key cultural developments occurred synchronically across Eurasia at this time and endeavored to find evidence of parallel developments to support this prediction. Most scholars follow Jaspers' centering of the Axial Age around the mid-first millennium BCE. The range of temporal boundaries offered for the Axial Age, however, varies widely across treatments, from $1400 \mathrm{BCE}$ to $650 \mathrm{CE}$, as demonstrated in Figure 1. Both proponents and critics of the Axial Age discuss the actions and legacy of figures ranging as early as Egyptian Pharaoh Akhenaten (e.g., Assmann 2012) and Zarathustra in roughly the fourteenth century BCE (e.g., Jaspers 1953, Joas 2012) to Jesus in the first century CE (e.g., Dalferth 2012) and as late as Muhammed in the seventh century CE (e.g., Casanova 2012). Thus, the temporal duration assigned to the Axial Age fluctuates widely from approximately two hundred years (e.g., 500 - 300 BCE; Baumard, Hyafil and Boyer 2015) to over 2,000 years (e.g., 600 BCE - 650 CE; Mumford 1956).

Largely, this fluctuation is the result of different interpretations of what specific transformations the Axial Age is meant to have entailed and, thus, which thinkers, movements, or societies qualify as 'Axial.' Akhenaten, for instance, inaugurated religious reforms stressing individual piety and promoting claims of universalism (Assman 2008; 2012); through this lens, Akhenaten, and Egypt of the fourteenth and thirteenth centuries BCE, stands as a clear Axial instance. Contrarily, these reforms were short-lived and did not involve major reforms to the legalinstitutional system or a more secularized legitimation of authority, hallmarks of many 
definitions of the Axial Age; in this light, then, $13^{\text {th }}$ and $14^{\text {th }}$ century BCE Egypt clearly does not belong and the boundaries of the Age need not be extended into the second millennium BCE.

While nearly all proponents follow Jaspers in centering the Age sometime during the first millennium BCE (notwithstanding differences in the onset and termination of the period; see above), several recent scholars stress that the actual impact of the transformative developments that first arose during the Axial Age only became manifest much later. In essence, this idea of a 'secondary' Axial breakthrough holds that the reforms and radical propositions of the great Axial sages like Buddha, Confucius, or Plato took centuries to develop and spread to the point where they became widely adopted as mature religious-ideological movements. Thus, many scholars argue that the great world-religions known today, including Buddhism, Christianity, Islam, and Rabbinic Judaism, each had its roots planted by these Axial thinkers (Bellah 2005; Casanova 2012; Stroumsa 2012; Tucker 1994; Wittrock 2015). As Bellah puts it, "Christianity and Islam fall outside the axial age chronologically, but are historically intelligible only as developments of Israel's axial breakthrough" (Bellah 2005:72). We discuss the implications of the different temporal ranges ascribed to the Axial Age by various scholars below.

\section{Axial Transformations Occurred Initially and Independently in a Handful of Geographically- Circumscribed Cases}

Jaspers (1953), and many others following him, identify five regions in which the Axial Age's proposed transformations took place: namely China, India, Iran, Israel-Palestine, and Greece. ${ }^{6}$ These 'Axial' regions are equated with their nearest modern country (see Figure 2), though it is important to stress that the precise extent of the geographical regions under discussion during the Axial period is rarely, if ever, defined. Jaspers (1953:10-11, 23) considered these cases to be autochthonous, representing "islands of light amidst the broad mass of humanity," which existed contemporaneously, but were "independent," "isolated," and experienced only "interrupted contact" until "only a few centuries ago and properly speaking not until our own day" 7 In fact, this supposed isolation was a major part of Jaspers' articulation of the idea of an Axial Age- the puzzling synchronicity of similar developments occurring in unconnected places. Social formations in Africa and the Americas, argued Jaspers, did not experience the 'axial' cultural breakthrough until the period of European imperial expansion. ${ }^{8}$ Bellah (2011), who recently reignited academic interest in the Axial Age, focused on just four of Jasper's five regions, noting that he was unable to examine ancient Iran for want of historical data. Armstrong (2006) also omitted the Persians, while Wittrock (2012) proposed five 'paths' of axial transformations that align with those of Jaspers (1953). Interestingly, little differentiation is made between the geographic regions associated with axial transformations and the scope of the religious or philosophical ideologies that form the basis of these Axial Age theories. For example, the transformations in East Asia (typically equated with modern China) are associated with the rise of Confucianism and are distinguished from those experienced in South Asia (India), which is associated with Buddhism. Figure 2 illustrates the geographical extent of the Axial Age as it is traditionally applied, following Jaspers. 


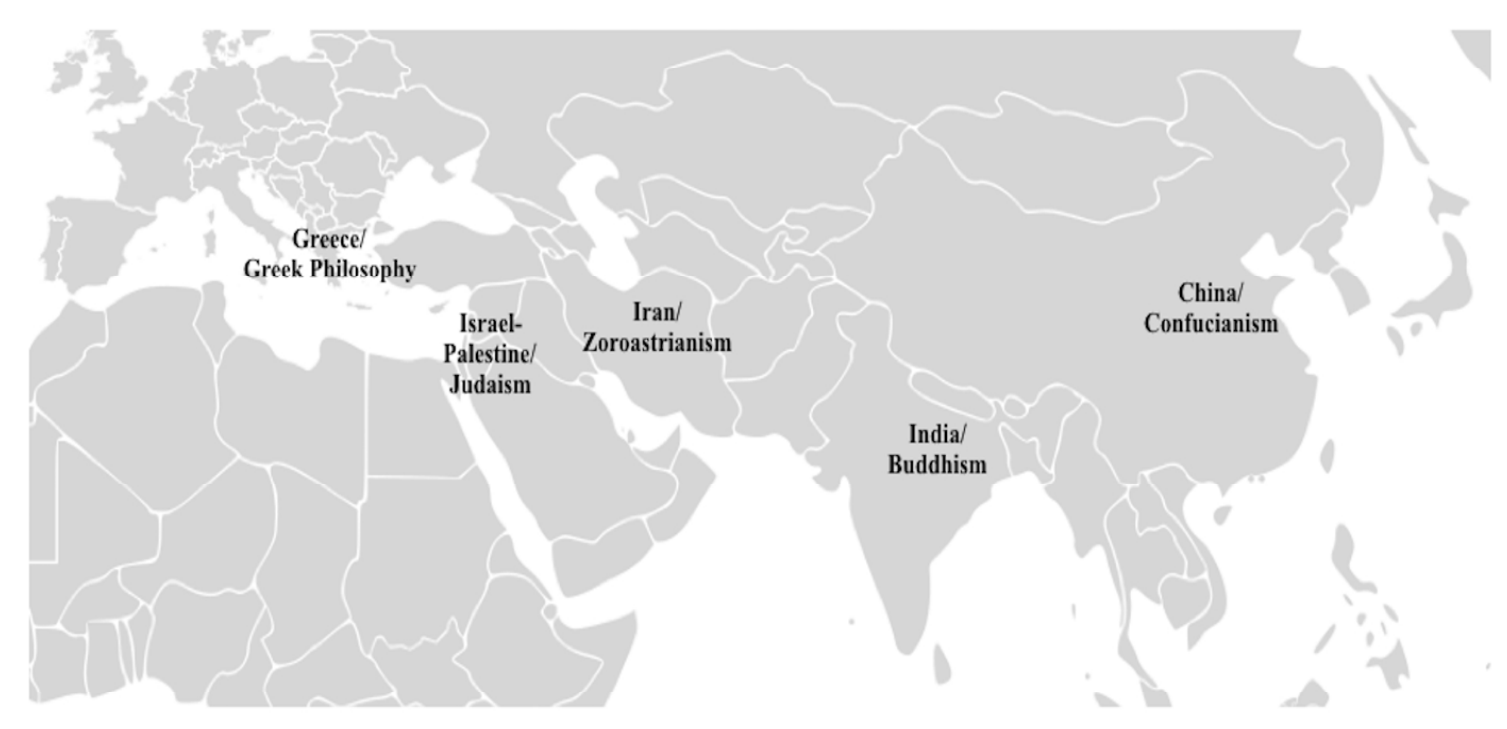

Figure 2. Map of the 5 Axial regions and ideological systems (800-200 BCE), following Jaspers (1953).

From these initial, seminal areas and ideologies, the ideas and radical new ways of thinking about society and one's relationship with power are said to have spread to every corner of the world. The precise nature and timing of this spread is rarely explicated in works on the Axial Age, but is implicit in the characterization of the Age as essential to the inauguration of many of the social, cultural, and political institutions familiar in the modern (Western) world (Arnason et al. 2005; Bellah 1970, 2011). Largely, the spread of Axial ideas is described as following the spread of the major religious movements the ideas helped create-Zoroastrianism, Confucianism, Judaism, Buddhism, and later Christianity and Islam. Having shaped these great ideologies that, in turn, shaped so many societies across Afro-Eurasia, the ideals of the Axial Age became permanent fixtures in subsequent sociocultural developments. The powerful, largely imperial states in Europe (Rome), Asia (the Han and subsequent Dynasties of China as well as the Mauryans in India), and the Near East (the various Persian Empires) - along with their successors - eventually spread their ideologies and institutional structures throughout the globe, through contact, influence, or colonial efforts in sub-Saharan Africa, the Americas, and the Pacific. Bellah speaks for all those living in the modern world - at least in the West-when he concludes, "Our cultural world and the great traditions that still in so many ways define us, all originate in the axial age" (Bellah 2005:73).

\section{Historical Inquiry Should Focus on a Handful of Seemingly Extraordinary Individuals}

Much ink has been spilt concerning the Axial Age to describe and compare the personal characteristics of a handful of historical individuals (e.g., Confucius, Plato, Buddha, Mani, Zarathustra). For example, proponents of the Axial Age continue to publish titles such as The Great Transformation: The world in the time of Buddha, Socrates, Confucius and Jeremiah (Armstrong 2006) and "Righteous Rebels: When, Where, and Why?" (Runciman 2012). These "righteous rebels" serve to personify the various philosophical, religious, social, and political transformations associated with axiality (See also Black 2008, Boy and Torpey 2013). Largely speculative biographies of these individuals are given as explicantia for the proposed transformations of the Axial Age. Consequently, this literature makes little reference to the causal factors and contextual dynamics that could explain what might have caused these 
individuals to develop arguably similar ideologies in disconnected areas. The focus on individuals in this literature further reinforces the idea of the Axial Age as a discrete historical period, a time during the lives of these sages when important changes developed. As noted, scholastic debates largely revolve around who should be considered a proper axial thinker. Basing a theory with such macro-scale relevance as the idea of the Axial Age on a micro-level focus on a handful of individuals presents several important problems about the precise timing, localization, and novelty of many of the key transformations that are said to have occurred during the Axial Age. We return to this critique in a following section, where we evaluate each of the 4 principal suppositions of the Axial Age concept in turn.

\section{Axiality rose out of major cognitive and intellectual developments}

Many proponents of the Axial Age, notably Jaspers, Eisenstadt, Bellah, and Baumard and colleagues, contend that this historical period witnessed the origins of modern ethics-focused and universalizing religions and novel ways of thinking about one's self and place in the world. They argue that individuals, who previously thought largely in terms of myth, the preservation of cosmic and social order, and mundane human experience, are said to have transitioned during this period to a reliance on rational, practical, and personal experience to order their activity within their changing social spheres. Religio-philosophical traditions that focused on notions of universal transcendence, salvation, redemption, liberation, and individual accountability are said to have emerged for the first time during this period. Jaspers (1953), for instance, made the connection between the Axial Age and the emergence of moralizing religions explicit, stating: "Religion was rendered ethical, and the majesty of the deity was thereby increased. The myth, on the other hand [...] was turned into parable." More recently, Taylor (2009; 2012) similarly argued that a form of reflexive cognition emerged during this period. He contends that the emergence of this new form of reflexive cognition instigated a moral revolution, leading to a greater emphasis on moral orthopraxy from both divine and secular authorities. This mirrors Eisenstadt and Bellah and colleagues' focus on the Axial Age as the time when second-order thinking emerged, or at least became a prominent feature of socio-political institutions (see above).

By this reckoning, the importance of the Axial Age is that, for whatever reasons, there emerged during this period in a few important locations a new focus on reflexive, second-order thinking, which led to a critical re-examination of prevailing social, cultural (including religious), and political institutions and customs. Subsequently (sometimes immediately, in other cases only after a prolonged period) this critical re-examination prompted radical reforms in the way that laws were constructed and applied to a populace, in the way that rulers legitimated their authority, and in the ideological, normative focus on moral, ethical, collaborative behavior. Finally, these reforms, when viewed en masse, formed the institutional foundation for the modern Western nation-state.

\section{LINGERING CRITICAL QUESTIONS SURROUNDING THE AXIAL AGE}

The Axial Age concept(s) has achieved widespread scholastic and popular appeal. As we detail above, there is a large degree of overlap between major accounts of the Axial Age and all recent works follows Jaspers' original articulation of the period. Nevertheless, the large number of thinkers who have engaged with the topic and the array of approaches that have been taken to characterize the period has also resulted in some disagreement about the age's chief attributes, 
causes, and consequences. Accordingly, many critical, outstanding questions remain concerning the Axial Age.

Partly, these issues are the result of the way that the Axial Age is often described; proponents frequently offer anecdotal evidence or qualitative historical narratives to couch their arguments in very general terms. What is declared is often vague, as for instance Eisenstadt's (2012:325) assertion that the period's axiality is "the historical emergence of certain visions in terms of which men have judged their everyday experience and everyday thinking." This vague language makes it difficult to pin-point exactly what the Axial Age entailed, what caused it, how and why it spread where it did (and did not), etc. Further, scholars have not always been consistent with how the concept is applied to specific historical cases. For instance, although many scholars do define explicit boundaries of the 'Age' (Figure 1), these boundaries are frequently and promptly ignored in practice as scholars attempt to accommodate processes and events that confound these temporal margins ${ }^{9}$, making this scholarship vulnerable to the charge of equivocation.

Another impediment to clarifying the ambiguities of this scholarship has been the lack of highquality, comparative historical empirical evidence. This has made it prohibitively difficult to adjudicate between competing accounts of the Axial Age in a systematic manner, track the key proposed transformations over long time-scales and large areas, or determine the precise boundaries of the principal developments commonly associated with the age. Indeed, Baumard et al. (2015:12) - hitherto the most ambitious empirical investigation of the causes of the Axial Age's transformations - were quick to point out the limitations of their work, stating that "more data would be needed to adequately test the robustness of [the affluence-hypothesis]. The proxies we used for affluence and political complexity remain very crude, and we hope that better data will become available in the near future." Unfortunately, much existing Axial Age scholarship is vulnerable to the charge of cherry-picking, presenting only evidence that conforms to the chosen pattern. For example, Jaspers specifically sought out historical evidence in favor of his conclusion that the Axial Age marked the beginning of the 'modern' way people view themselves and their place in the world (Jaspers 1948).

It is precisely to provide such large-scale, comparative historical-sociological analyses that we developed the Seshat Databank. In the following section, we present the results of a systematic exploration of a large body of historical evidence designed to put different conceptions about the Axial Age to the test and determine the extent of the idea's applicability against the historical record. Before this, however, we discuss lingering conceptual questions or interpretive issues regarding each of the four principal suppositions outlined above, as made by prominent Axial Age proponents.

\section{There was a Historically Discrete Axial Age}

The idea that the major axial transformations arose roughly synchronously in a discrete historical period underpins the basic concept of the Axial Age. This temporal bounded-ness is, indeed, central to Jaspers' original conception and has remained an important part of subsequent accounts. As we note above, however, although nearly all advocates of the Axial Age agree that the center of the period should be placed at the mid-first millennium BCE, a wide array of alternate bounds for both the beginning and end of the 'age' have been proposed. Thus, the principal features of axiality may be found to occur outside of the historical periods associated with the Axial Age when these features are investigated across wider timescales (Smith 2015, Wagner 2005). This has been the case in studies that focused on the 'axial' nature of figures from 
Akhenaten, Jesus, and Mohammed. Voegelin (1974:4), who articulated an early criticism of the temporal dimension assigned to Axial Age hypotheses, is worth quoting directly:

In order to elevate the period of 800 to 200 B.C., in which the parallel outbursts occur, to the rank of the great epoch in history, Jaspers had to deny to the earlier and later spiritual outbursts the epochal character which in their own consciousness they certainly had.

We further contend that the four or five germinal cases of axiality identified by Jaspers (1953) and others may not have been as contemporaneous as they are typically presented. Indeed, a growing number of critics approaching the topic from different perspectives have argued that there is no single historically-discrete period of profound contemporaneous cultural transition (e.g., Black 2008, Norenzayan et al. 2016, Provan 2013, Stroumsa 2012, Voegelin 1974).

These are not mere semantic issues; if the central features of axiality cannot be tied to a specific and identifiable time-period or periods, then the concept of an Axial Age is of limited theoretical utility and focus should shift from an investigation of a temporally-bounded 'age' to investigations of potential examples of 'axiality' free from this temporal constraint. Unfortunately, no single analytical study has explored a large number of cases together, combining examples of both axial and non-axial societies within a wide timeframe. It is of critical importance, then, to determine through careful examination of the historical record the precise temporal bounds of the Axial Age, if there indeed was an Age, as opposed numerous moments of axial-type transformations.

\section{Axial Transformations Occurred First and Independently in a Handful of Geographically- Circumscribed Cases}

The early and sustained focus on four or five core cases of axiality is largely explained by a methodological commitment to the examination of the temporally delimited 'age' (discussed above). Because of this temporal constraint, promising additional cases of axiality are often excluded, ranging from Pharaonic Egyptian to Islamic civilizations, though as noted some recent commentators have stressed the potential 'axiality' of these non-traditional cases (Arnason, Salvatore and Stauth 2006, Norenzayan et al. 2016). This a priori commitment to a handful of supposedly germinal cases has left open several important issues. Even though most Axial Age hypotheses are global in their scope - aiming to pinpoint the inauguration of the 'modernity' which eventually reached the entire globe - the arguments and evidence submitted in their favor are typically generated from a mere handful of cases. Thus, while it is very compelling to loosely compare crucial innovations in Greece, India, or even Egypt, for example, restricting arguments to only the positive examples begs the question of whether other regions at other periods experienced an axial transformation or something similar. It is also puts into doubt any claims about the specific factors causing the regions that did undergo an axial transformation, for without demonstrating that the non-axial cases did not exhibit those factors, any such claim must be regarded as specious. Further, even the scholars who argue for the importance of secondary axial breakthroughs focus on the spread or adoption of 'axial' ideologies in the first millennium $\mathrm{CE}$ in a handful of regions, overlook other time periods and world regions, and fail to account for areas that did not experience these "breakthroughs", making it difficult to interpret claims about the nature of the spread of axial ideologies. To address these issues, a more representative sample of regions must be compared directly, incorporating both the core axial areas and regions not traditionally associated with the period. 


\section{Historical Inquiry Should Focus on a Handful of Seemingly Extraordinary Individuals}

"Great men" approaches to historical analysis have been roundly criticized at least since Spencer (1892) argued that the actions of individuals are best understood when discussed in the context of their contemporaries. Much work on the Axial Age is vulnerable to these same critiques, attributing large-scale societal changes to the work of "the great axial prophets and sages" (Bellah 2005:17). Granted, often these individuals are used to stand in for a wider movement, such as Plato being the culmination/representative for a larger Mediterranean trend towards secular metaphysical and political philosophy at the end of the Greek archaic period. Still, focusing arguments on biographical depictions of 'great men' obscures the more macro-level context and long-term dynamics that both inspired the sages' novel ideas and helped spread these important innovations around Afro-Eurasia. Such a macro-level and long-term investigation is needed to explain the why and how of the Axial Age, issues that remain unresolved by the existing literature.

A related issue, strongly related to the periodization of the Axial Age, is that there is often a significant time-lag between the rise of these so-called 'axial sages' and the widespread adoption of their ideologies or prescriptions either as an official state religion or by the general public (Assmann 2012:399). The rise of Buddhist thought as a dominant ideology throughout India, China, and Southeast Asia, for instance, took hundreds of years after the birth of Siddhartha Gautama sometime in the mid-first century BCE. This resulted in a great deal of heterodoxy in the formulation and practice of Buddhist ideals, which are mixed with elements of Hindu, Confucian, and other preexisting ideologies in these different regions (Coningham 2001, DeCaroli 2004). By itself, this gradual and heterogeneous spread of an axial ideology does not invalidate the concept; indeed, such a secondary emergence of axiality is a fundamental part of many scholars' arguments (e.g., Wittrock 2015). It is, nevertheless, a conceptual challenge to determine the explanatory force of the Axial Age when the temporal specificity initially given to the concept (the 'age') is blurred to allow for more gradual long-term changes. This begs the question-is the Axial Age an age? If the key breakthroughs occurred in the first millennium $\mathrm{CE}$, why focus on individuals from the first millennium BCE? If we relax or remove the temporal specificity, does that bely the notion that the so-called axial sages were such generative, transformative thinkers, and should we instead focus on the precedents or historical-sociological contexts that are most likely to have facilitated the axial transformations that are said to have occurred in different regions at different times?

\section{Axiality rose out of major cognitive and intellectual developments}

Jaspers (1953) argued that the defining characteristic of the Axial Age was the capacity and desire to transcend mundane existence and reflect critically on mythological forms of power and authority. Many prominent advocates of the Axial Age have extended this focus on critical, reflexive thought as the major intellectual development, the prime cause that instigated all of the major institutional revolutions characteristic of the period. Eisenstadt has been particularly forceful in this regard, arguing that a core of axiality is "a radical problematization of the conceptions of cosmological and social order, and with growing reflexivity and second order thinking" (Eisenstadt 2005:537). The idea that the period was largely one of major changes in the way that people thought or considered their role and place in society is indeed an intriguing, even compelling way to view the period. Arguments focused on such cognitive breakthroughs, however, tend to rely on very elaborate prose descriptions, rather than clear expositions of empirical evidence. Notably, it remains unclear how precisely these cognitive developments are 
meant to have been spurred, whether they are the product of particularly generative actors (the axial sages) or whether they were widespread ideas that coalesced in the writings of particular thinkers, and whether these supposed cognitive developments were actually the cause of the Axial Age's other transformations or should more properly be viewed as the result of large-scale socio-cultural and political developments. We further question the plausibility that these crucial cognitive changes could occur in such a localized manner-arising in a small number of individuals in a handful of areas during a very precise time, rather than as the result of long, slow, large-scale evolutionary processes (Mesoudi 2011; Pagel et al. 2007; Richerson and Christiansen 2013).

Indeed, some recent studies in cognitive psychology have sought to place these ideas on firmer theoretical and empirical grounds, analyzing large amounts of textual evidence to uncover general patterns in reflexivity within human societies both current and past. For example, Mota et al. (2016) likens the low degree of reflexive or introspective thought expressed in Bronze Age texts across Eurasia to adolescents in modern western countries, while texts produced during or after the Axial Age are argued to mirror the level of introspection in contemporary adults. Even if such results, which rest on a fairly narrow selection of source material, are accepted, it is unclear exactly how this would translate into an argument for widespread cognitive changes. These patterns in the literary expression of introspective or reflexive thought seem better characterized as the result of cultural changes or generic changes in the accepted, common ways authors have of expressing their worldviews. This, indeed, is the conclusion of another recent study, which found after a similar analysis of contemporary and ancient texts that levels of reflexive thought have ebbed and flowed over time due largely to socio-cultural factors, rather than exhibiting a clear disjunction between any pre- and post-axial period (Diuk et al. 2012).

\section{EMPIRICAL EXPLORATION OF AXIAL AGE ARGUMENTS}

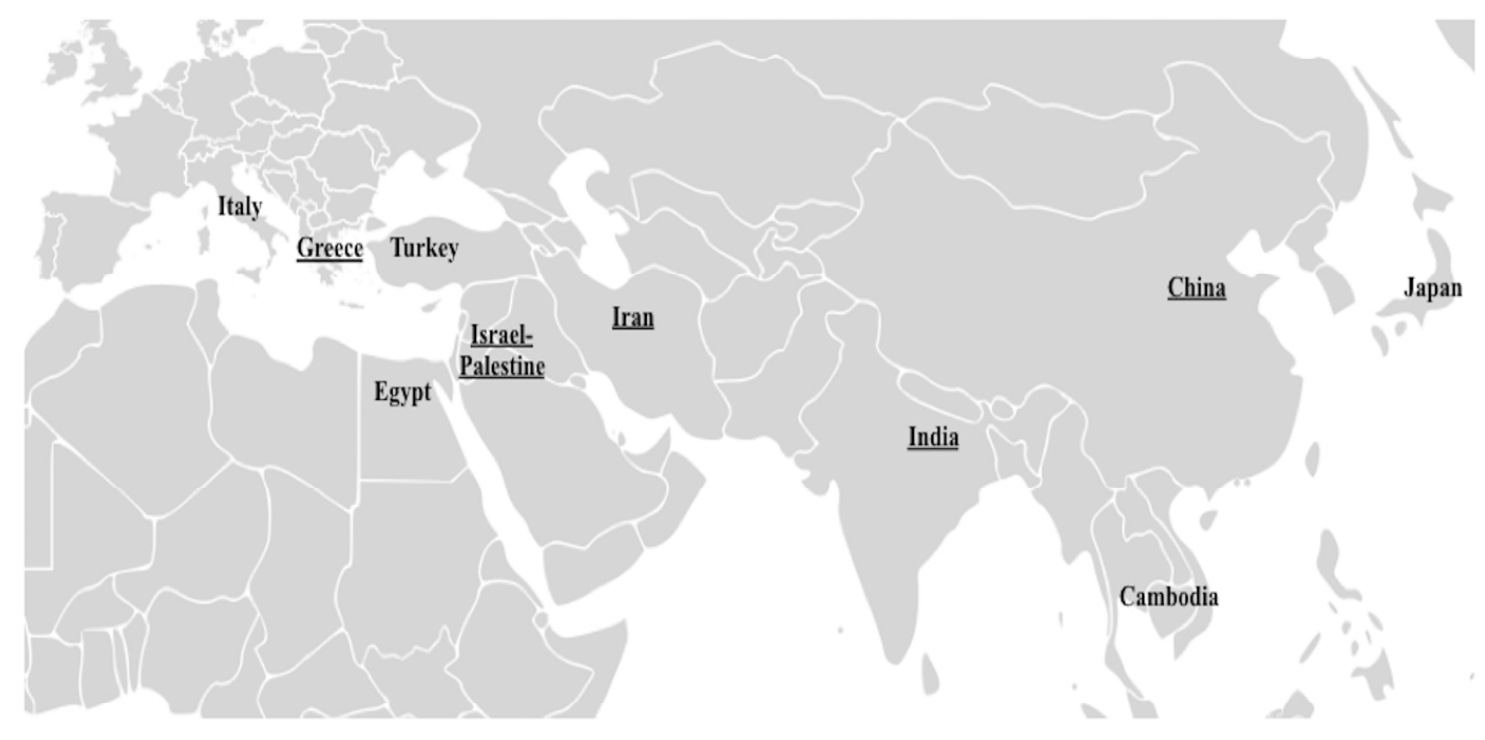

Figure 3. Ten regions sampled for analysis. Five conventional Axial Age regions are underlined.

The previous section highlighted a number of open questions about the Axial Age. The questions are large in scope and getting to the bottom of these issues requires careful, systematic 
examination of a wealth of empirical, historical evidence. Fortunately, new methods provided by the emerging field of Cliodynamics enable researchers to tackle 'big questions' and explore historical processes over the longue durée, such as the proposed Axial Age transformations. One of the largest and most developed projects following this approach is the Seshat: Global History Databank (Francois et al. 2016, Turchin et al. 2012, Turchin et al. 2015). Seshat's methodology provides unique advantages for conducting empirically-informed, systematic, historicalsociological analysis. Notably, Seshat's long timescales allow for a more rigiorous examination of the temporal boundaries of the Axial Age, while its global coverage allows analyses of a more inclusive sample than has previously been employed, extending beyond the standard set of allegedly "axial" cases. ${ }^{7}$

Here, we offer a detailed discussion and survey of a large body of historical evidence drawn from the Seshat Databank. We explore the empirical record from both five widely-discussed axial cases (Greece, Israel-Palestine, Iran, India, and China) along with five regions not typically associated with axiality (Italy, Turkey, Egypt ${ }^{10}$, Cambodia, and Japan) (Figure 3). We further track key historical-sociological dynamics in these 10 regions across the five millennia spanning from the third millennium BCE to the second millennium CE; our sample, thus, encompasses the various ranges offered by different Axial Age proponents (see figure 1) and captures material from both before and after the central 'age', a crucial step in determining the precise timeline and context within which axial transformations occurred. This novel investigation aims to resolve or at least bring new clarity the key lingering questions concerning the Axial Age. In the process, we uncover new questions for future study, which we discuss in the concluding section. We hope also with this discussion to illustrate the utility of a quantitative, analytic approach to the topic, pointing the way to future studies pursuing the implications of these initial findings.

\section{Methodological Considerations}

To test these lingering questions systematically against the historical record, we identified proxy measures for the key axial transformations commonly highlighted in scholarship on the Axial Age (Table 2). We then dynamically track these proxies (at century-long intervals) for each of the ten regions in our sample, assessing whether each proxy measure was present as a feature of any of the prevailing ideologies in each sample region at any given time between the third millennium BCE and the second millennium CE: present was encoded as ' 1 ', not present as ' 0 '. For each region, we look at the various societies - polities $^{11}$, as we term them-that occupied the region at any given point during this time frame. It is from these polities that we draw empirical historical evidence, putting all of the data together to generate long time-series. The historical material we use was gathered and stored by Seshat: Global History Databank, combining primary and secondary literature for a host of different historical periods and sub-topics for evidence concerning these proxy measures. This approach seeks to capture benefits from both quantitative and qualitative historical analyses (Francois et al. 2016). To ensure we had up-todate information and understood scholarly disagreements about these topics, we corresponded directly with several "domain experts", including historians, archaeologists, anthropologists, and scholars of religion, and our personal communications with these experts are cited throughout.

Critically, we incorporate material concerning both the dominant (i.e. tied to state authority) and popular or subaltern philosophical, cultural, religious, and ideological systems in each region during each temporal interval. For instance, when gathering information on 'Greece' at 300 BCE, we explored evidence from both the many philosophical schools popular with certain Athenian elites (which are stressed by Axial Age proponents, following Jaspers), and scrutinized 
the practices and belief-systems of the more widely held, popular pan-Hellenic religious practices. This allows us to disentangle the influence of different ideologies on wider social, cultural, and political institutions and to assess the context in which particular 'axial' ideas arose and spread. It also adds an important balance to traditional scholarship on the topic, which, as explained above, can become fairly myopic, focusing on the established axial ideologies while disregarding potential facilitating or limiting factors from non-axial traditions.

The proxies used here (Table 2) capture the key attributes or innovations of the Axial Age ascribed by most prominent authors (cf. Table 1 and following discussion). Dividing up the predictions into sets of proxies allows us to capture change over time and variation in the different dimensions of the complex ideological precepts highlighted in previous work on the Axial Age. A major issue with attempts to quantify and assess the claims made by Axial Age proponents is that, as noted above, the driving force of the period according to many prominent scholars was fundamental changes in cognitive and intellectual capacities. Arguments about broad changes in ways of thinking in the past, such as Eisenstadt's (1986:1) claim that period saw the creation of "a higher transcendental moral or metaphysical order," are impossible to measure directly. Future work is necessary to attempt to disentangle these cognitive claims, seeking to develop innovative proxy measures or identify material/textual traces that could allow researchers to diagnose the emergence of such reflexive, second order thinking at specific moment(s) in the past. Fortunately, the logic of arguments about the Axial Age permits more ready historical investigation. For example, changes in cognitive expression are said to have led - through various processes and at differing paces - to very tangible changes in key social, cultural, and political institutions at specific places and times. These tangible changes are discernible in the historical record and are captured by the proxies used here.

The proxies in Table 2 seek to capture the principal dimensions of the universalizing, moralityfocused and ruler-constraining ideologies that supposedly developed during the Axial Age. Proxies 1-7 relate to the alleged institutional changes that resulted from the changes in cognitive focus and novel ideologies spread by the axial sages and their adherents. These 7 proxies seek to measure how the innovative precepts that, it is argued, arose during the Axial Age: through the manifestation of these ideals in the dogma or normative claims of both prevailing and subaltern ideologies (proxies 1-2), in the proclivity of people to take these messages to heart and engage in community-enhancing, prosocial activity (proxy 3), as well as in the rules and claims surrounding the relationship between rulers and the divine and the common people (proxies 4-7). Proxies 8-12 follow from the others, capturing how these ideals became entrenched in the institutional structure of the societies in question. Indeed, to many, the novel claims and moral focus of axial ideologies have had such a profound and lingering impact because of the specific social, political, and legal institutional changes they engendered. Broadly, proponents of the Axial Age distinguish archaic states, typified by autocratic (often divine or divinely-sanctioned) rulers along with under-developed and unevenly applied law, from post-axial states which look more like the representative bureaucratic societies we are familiar in the modern West. 
Table 2. Summary of key proxies used to evaluate Axial Age concept

Proxy Name

1 Moralistic punishment

2 Moralizing norms

3 Promotion of prosociality

4 Omniscient supernatural beings

5 Rulers not god

6 Equating elites and commoners

7 Equating rulers and commoners

8 Formal legal code

9 General applicability of Law

10 Constraint on executive

11 Full-time bureaucrats

12 Impeachment
Proxy Description

Captures the idea that actions will be judged and punished in this life or the afterlife, either directly by supernatural agents or by human religious agents working on their behalf (defined as members of religious groups, their leaders, or other religiously motivated individuals, e.g., Buddhist monks, street preachers). This idea is central to claims made regarding the rise of universalizing, moralizing ideals during the Axial Age; recent work has pointed out that the widespread application and enforcement of moral norms and taboos was key to the rise and spread of universalizing religions from the Axial Age to the modern day (Baumard and Boyer 2013, Bellah 2011, Casanova 2012, Norenzayan et al. 2016). Captures the importance placed by Axial Age proponents (e.g. Baumard et al. 2015, Bellah 2011, Eisenstadt 2005) on how axial thinkers stressed moral and ethical conduct and insisted upon a moral basis of rulers' authority - rather than relying on "archaic" ideas of divine sanction, military strength, or simple tradition.

Captures whether or not axial ideologies and their proponents were indeed concerned with taking care of the well-being of co-religionists, fellow-citizens, or perhaps all of humanity; (Atran 2016, Turchin 2012). Prosociality is operationalized here as the promotion of prosocial activity by religious and philosophical thinkers and their followers, as well as by the actions it spawned, including wide-spread acts of charitable giving or the creation and/or maintenance of public goods. "Public goods" refers to anything that incurs cost to an individual or group of individuals, but that can be used or enjoyed by others who did not incur any of the cost, namely the public at large. They are non-excludable and non-rivalrous goods (e.g., roads, public drinking fountains, public parks or theatres, or public temples).

Captures the concept of omniscient supernatural beings and addresses the recent contention that that the axial period saw supernatural beings become increasingly concerned with the proper, moral thoughts and actions of constituents (Assmann 2008, Eisenstadt 2005, Jaspers 1953). The authority of the autocratic 'god-kings' typical of the archaic period is predicted to have been reduced, while the secularized legitimation by rulers increased.

Captures the Axial Age concept that Axial gods are more omniscient (i.e., all-seeing, all-knowing) than non-Axial ones. Claims made about the divinity of rulers, either in this world or the afterlife, were a common means of expressing an extreme differentiation between people in a society, meant to be characteristic of pre-axial societies (Bellah 2011).

Captures the adoption of axial thinkers' predicted promotion of more universalizing moral claims and increased socio-political equality. Bellah (2011:573) notes that it is "part of the definition of the axial age that it was then that a universally egalitarian ethic first appeared."

Captures potential increases in the ideological promotion of equality. Eisenstadt (2005:534) notes, "Of special importance in shaping such different institutional patterns [as emerged through axial transformations] is the degree to which elites are autonomous or embedded in ascriptive units, or act as representatives of such units in the society, as well as the relation between different elites and the broader community."

Captures the existence of a body of formalized (usually written) laws and ascribed punishments governing inhabitants' actions.

Captures whether legal codes were applied generally, namely to all residents of the society (including the ruling elite), or whether different segments of the population were subject to different regulation.

The idea of rulers being subject to laws is a critical component of the apparent moralizing and universalizing ideological reforms of the period.

Captures potential institutional reforms that limited the arbitrary and exploitative power of rulers from a political rather than legal angle, asking whether there was any mechanism or office that had the power to veto or overturn a decision of the ruler (including removing a political appointment), or withhold cooperation (e.g. refuse to fund a venture).

Captures whether there were specialists engaged in administration, as opposed to, for instance, elites who volunteered time and resources to fulfill administrative or official duties. This proxy captures the degree of regulation of and accountability over the behavior of rulers and their agents as well as to the separation of political, administrative activity from other spheres (e.g. religious).

Captures the power of people in a society to constrain and even punish the activity of rulers, reflecting a high amount of non-conformity or obsequious to authority. 
Indeed, Bellah (2011:264) follows others in describing the "massively conformist archaic society" as a place where "obedience" to traditions and to the ruling authorities was paramount, and a civilization typified by the "centralization of political power....the economic exploitation of the weak." Eisenstadt in particular stresses this aspect of axial transformations, arguing that during this time "there emerged the conception of the accountability of the rulers and of the community to a higher authority, God, Divine Law, and the like....Concomitant to the emergence of conceptions of accountability there began to develop autonomous spheres of law and conceptions of rights" (Eisenstadt 1986a:8). Our proxies capture whether elite power became subdued under more formal, universally applied legal regulation (proxies 8,9 ) as well as track the degree to which ruler's autocratic power was reigned in (proxies 10, 12) as axial ideologies took hold in a society and whether centralized, conformist 'archaic' rule became de-centered and regularized (proxy 11).

RESULTS: SYSTEMATIC EMPIRICAL ASSESSMENT OF AXIAL AGE PROPOSALS ${ }^{12}$

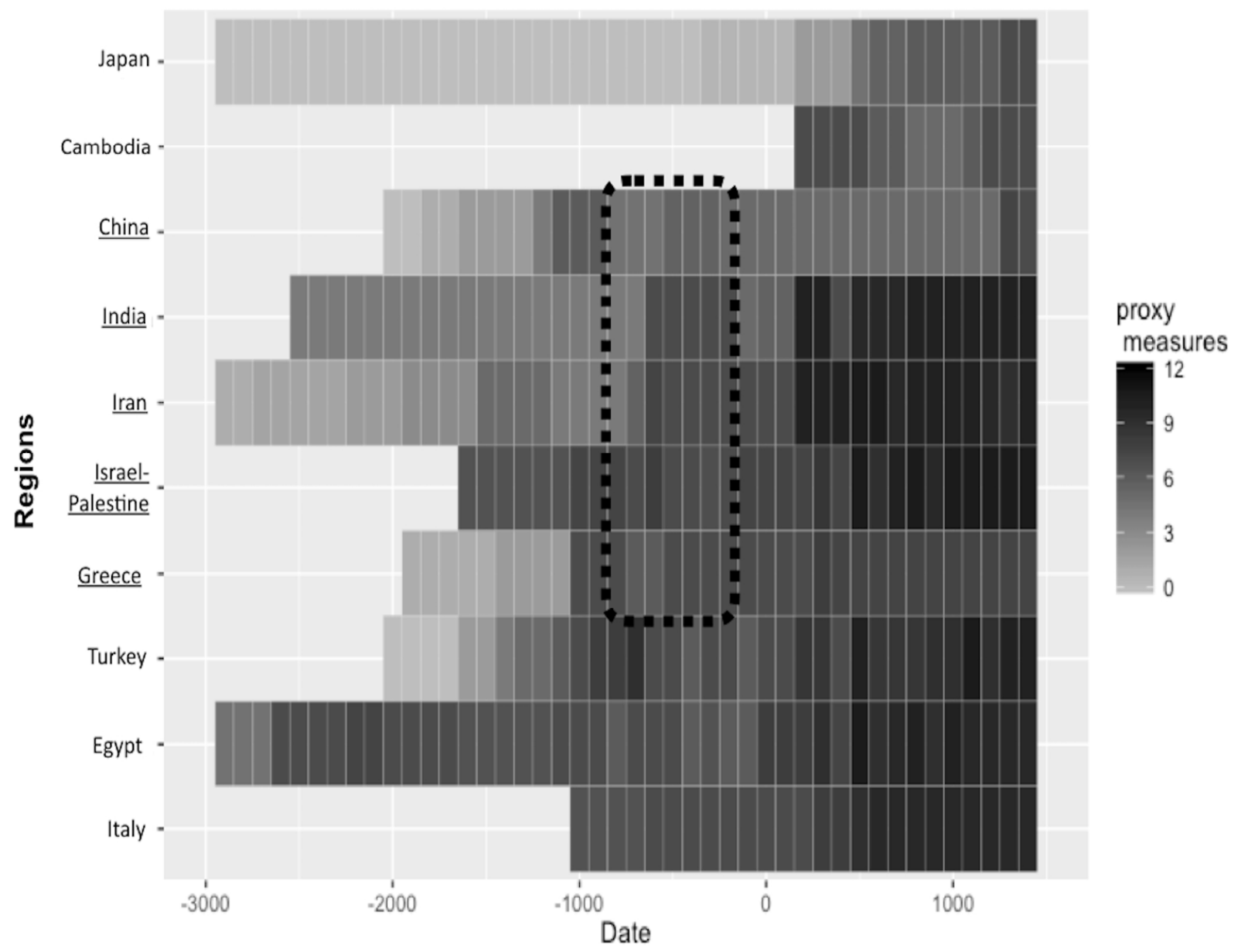

Figure 4. Tracing the number of axial traits in each region over time. Calculated by observing the presence (=1) or absence $(=0)$ of the 12 proxy measures in each region at 100-year intervals and summing the results.

Underlined regions are the core Axial regions. 
Using the proxy measures outlined above, we closely examined the key conjectures that have been made about the Axial Age against a large body of historical data. We explore evidence from 10 select regions across Afro-Eurasia, chosen to include both the 5 "core" regions traditionally associated with axiality as well as 5 ostensibly "non-axial" regions, or regions that fall outside of most discussions of the Axial Age. Somewhat surprisingly, we find very little support for many of the central ideas put forward about the Axial Age and the way it has been characterized, although some of the notion's essential features do receive empirical support (Figure 4).

We see clearly that new ideologies stressing universalizing moral religio- philosophical principles emerged in a handful of regions across Afro-Eurasia. In partial support of the Axial Age concept, crucial proxies are indeed present in the 5 core axial regions (Greece, IsraelPalestine, Iran, India, China) during the latter half of the first century BCE, as expected. However, contrary to the Axial Age concept many proxies are also present before this period in several regions, belying any claims that there was a specific age of axiality. Further, we see many of these proxies arise in the 5 regions not traditionally associated with axial transformations (Egypt, Turkey, Italy, Cambodia, Japan) both before and after the normally proposed age. It is difficult to conclude, then, that these key axial principles and the social, cultural, and political transformations they allegedly spawned emerged initially and exclusively in a handful of regions across Afro-Eurasia and during one specific moment in history.

Interestingly, the adoption of axial traits in several regions, particularly the non-traditionally axial ones, similarly fails to support many of the arguments made by Axial Age proponents, who stress the importance of 'secondary breakthroughs' of axiality, such as the rise and spread of Christianity and Islam. This result raises serious questions about the dynamic trajectories of axial traits ascribed by prominent Axial Age scholars and calls for a re-evaluation of the nature and impact of the supposedly 'core' axial transformations. There also appear to be both rises and declines in the aggregate presence of these measures, suggesting that whatever changes occurred were not as stable as is often implied.

On the other hand, there is support for some of the key ideas about the Axial Age. Generally, each region explored here did, during certain time periods, witness the appearance of all the measures of axiality under analysis. It is clear too that important ideological, religious, and/or cognitive developments are associated closely with radical reforms of the social, cultural, and political institutions in many of the societies under question. Further, these transformations certainly have had a profound and lingering impact on subsequent societies, including up to the present day, even if they became established through several fits and starts.

Again, the Axial Age, in its most distilled and common articulation, contends that new ideologies were brought into being by great sages in five primary regions during a specific 600 year period (800-200 BCE). These ideologies are said to have empowered by novel forms of reflexive cognition and prompted dramatic cultural and institutional reforms. This concept does not hold up to systematic empirical scrutiny; the historical evidence simply fails to corroborate the idea of an Axial Age that is clearly circumscribed geographically or temporally. This does not necessarily invalidate the amorphous concept entirely, however. As noted above, scholarship surrounding the Axial Age concept has offered a wide variety of claims with more-or-less relaxed bounds and causal chains. What it does is challenge the way that the Axial Age is typically defined and expressed, raising in its stead a host of critical questions that must now be subjected to close examination against the historical record. 
Notably, if axial transformations did not occur in the time and location typically proposed, then when and where did they first occur? How did they then spread? What role, if any, did the oftenhighlighted axial 'sages' play in these processes? How do the cognitive developments highlighted by many scholars relate to other transformations? Perhaps the most crucial of these questions, though, relates to the causes and effects of various axial transformations. If it is not discernibly the case that ideological/cognitive developments led to novel religious and philosophical ideals, which in turn fostered reforms in legal and political institutions, which have had a lingering impact on subsequent social formations, then what was the key change that caused the others? Did institutional changes actually come first, instigating the observed cultural and cognitive shifts? Were the religious and philosophical ideas actually based on earlier precedents, which only became crystalized and prevalent once certain institutional developments had occurred? Or is there some other critical factor or factors missing from these discussions that could explain the rise and spread of all these diagnostically 'axial' traits? To further explore these important and, perhaps, unexpected alternative proposals, see our online supplement, which offers analytical summaries of the available historical data for each of the 10 regional cases explored here.

\section{DISCUSSION: QUESTIONS ANSWERED AND RAISED ABOUT THE NATURE, EXTENT, AND SPREAD OF AXIAL TRANSFORMATIONS}

Seshat: Global History Databank provides a novel opportunity to explore the many facets of the Axial Age in a more comprehensive, systematic, analytical manner than has generally been employed. We take a Cliodynamic approach, combining the wealth of historical information gathered by the Databank with quantitative methods to offer a novel exposition of the central features shared by most prominent Axial Age scholars as well as a systematic exploration of the key propositions against a large body of empirical historical evidence. The aim is to scrutinize a broad sampling of past societies - both temporally and geographically — to detect if the proposed transformations occurred when, where, and how they are typically proposed. This exercise helped to dispel some of the problematic aspects of previous arguments concerning this important period in human history while revealing many new questions that require further, systematic study to disentangle.

The dominant insight that jumps out from close scrutiny of this large body of historical evidence is that there is no clear pattern; the 5 purportedly 'core' axial regions do not manifest the traits and structures that arguments concerning the Axial Age concept suggest. In each of the societies explored (with the exception of archaic and classical Greece), there already existed fairly strong moralizing ideologies. This is, on its own, certainly not surprising - it is difficult to imagine a society functioning without moralizing norms. Its significance lies in the fact that there is no obvious change over time, belying the notion that the first appearance of, or at a least dramatic increase in, the moral force of ideological precepts came about with the novel philosophical and religious traditions that emerged during the first millennium BCE (cf. Baumard et al 2015:10). It could be argued that the proxies we use to measure the rise of moral norms (especially proxies 12) are too crude to pick up on the more intricate dynamics underpinning 'axial' change. Importantly, our other proxies and the more detailed survey of each of these 5 regions raise similar doubts about the traditional Axial Age concept. An increasingly strong and impactful moral force should also be manifest by the way that gods and rulers are conceived, with rulers becoming secularized as their authority is legitimated more through institutionalized, ethical standards than notions of divine right, while gods become more all-knowing and more capable of 
assessing and punishing moral norms (with the help of empowered religious agents). Yet, this is not uniformly evidenced by the societies under analysis here.

The 5 allegedly non-axial regions we explored present a similarly problematic picture. Some areas - Egypt, Turkey, and to some extent Italy - display very clearly axial-type transformations well before the lifetime of the axial sages normally discussed. Even in these cases, though, not all of the key axial traits that are generally said to co-occur developed at the same time, raising doubts about the scope of common arguments about axiality. It is notable as well to explore cases with later transformative periods, such as Japan and Cambodia. Japan, as noted, is wellknown for being explicitly excluded from the realm of axial societies by Eisenstadt (1996), even though there was a strong presence of the ideological triggers that supposedly facilitated axial transformations in the form of Shinto and then Buddhist thought elsewhere (e.g., China). Likewise, Cambodia saw what might be termed a secondary axial breakthrough during the first millennium $\mathrm{CE}$, though curiously this occurred before the ascension of Buddhism as the major ideological force in the region.

Deliberately looking for signs of axiality in the regions that are typically excluded from discussions of the period is a crucial and innovative feature of our method. It allows us to determine that axial transformations were not the exclusive purview of the temporally and geographically bounded set of cases offered as core axial regions since before the writing of Jaspers. At the same time, analysis of these areas reveals that axiality does not follow the same course in every location: sometimes strong moralizing norms were reinforced through divine sanction and punishment (as in Israel-Palestine and Egypt), sometimes not (Greece, Italy); sometimes egalitarian ideals led to real systematic reforms in the relationship between rulers and ruled (Iran), sometimes not (China, India); and sometimes well-regulated and formalized institutional features developed that effectively limited the arbitrary, divinely-sanctioned authority of rulers and hold all people accountable (China, Iran), sometimes these traits did not all co-occur (Egypt, India).

As we saw, there was an upward trend during the first millennia BCE-CE towards increasingly widespread, universalizing claims of authority and the ideological reach of these claims as several states became large imperial powers, spreading their messages and systems of rule across huge swaths of territory. Further, many of the important institutional reforms highlighted by work on the Axial Age concept do show up at roughly the right time in the late first millennium $\mathrm{BCE}$ - rulers in the societies that occupied these regions indeed become more restrained in their activity over time, legal regulation becomes formalized and is extended to the whole of society, and more complex and well-regulated administrative regimes appear. Conversely, these innovations are not experienced equally, nor are they always permanent. In other words, key markers of axiality, which are proposed to have emerged en masse, are shown to have emerged in fits and starts, if at all.

Importantly, the allegedly axial ideologies explored here do exhibit more pronounced claims of equality than most ideologies that preceded them, particularly by limiting the authority and privilege of rulers and asserting the requirement that all members of society be taken care of by those with power. However, these ideologies are also shown to have been highly circumscribed and were not as "universalizing" as is often argued (cf. Arnason 2005:23, Bellah 2011:264, Eisenstadt 1986b:37). For example, the supposedly universal morality and egalitarianism of these ideologies did not extend to women, who were not afforded equality with men in these societies in terms of legal rights, ritual function, social status, or other areas (Larsen, 2017 pers. comm.; Kant 2003, Rose 2015), notwithstanding apparent claims in, for instance, Zoroastrianism 
for gender equality (Rose 2015:273). Such gender distinctions, even when they existed only in practice and not as an explicit stance of a society's dominant ideology, undercut the notion that Axial religions and philosophies ushered in radical reforms about the universal applicability of rights and responsibilities and reflexive, critical thinking about the archaic structures that sought to differentiate segments of the population.

Our systematic analysis of a large body of empirical historical data reveals that there was no single, well-defined, and bounded Axial Age, no "axis of world history [...] the point in history which gave birth to everything which, since then, man has been able to be, the point most overwhelmingly fruitful in fashioning humanity" (Jaspers 1953:1). Our method of analyzing the Axial Age concept demonstrates the benefits of systematically exploring the historical evidence and of taking a more inclusive and representative sample of cases than has been offered previously, looking explicitly for both positive and negative instances of axial transformation. It also demonstrates the necessity for splitting apart the various strands of Axial Age arguments into constituent parts, assessing the - possibly conflicting — dynamics of different key axial traits.

Nevertheless, as our analysis makes clear, the Axial Age concept is not devoid of merit. Important developments extending and reifying certain moralizing norms, emerging concepts of supernatural beings as omniscient and capable, along with their agents, of punishing transgressions to enforce these norms, incentives to act prosocially, limits (in some cases) on the social and legal inequalities between classes, increasingly complex and formalized institutional procedures, and reduced claims to divinity and secularization of legitimation by rulers all did occur in many places throughout Afro-Eurasia; they just did not occur in precisely the places, times, and manner purported by major advocates for the concept of an Axial Age (Arnason, Salvatore and Stauth 2006, Arnason 2012, Assmann 2012:376, Provan 2013:34). We are left, then, with more questions than answers. Seven key questions for further research as summarized in Table 3.

While further cross-disciplinary work is needed to properly address these fundamental questions, we contend that a quantitative, Cliodynamic approach offers the best chance to find answers through the systematic scrutiny of alternate hypotheses and the further development of the dataintensive empirical investigation employed here. In particular, more substantial investigation is needed to fully disentangle the predicted emergence of second-order thinking (e.g., Eisenstadt 2012) from other elements of axiality, or the potential link between the Axial Age and increases in historical measures of affluence (Baumard et al. 2015).

One intriguing possibility for the latter idea is that the affluence identified by Baumard and colleagues as holding great causal weight in instigating the transformations ascribed to the "Axial Age" was itself the result of, or at least strongly correlated with, composite elements of social complexity. In fact, a detailed analysis of the relationship between social complexity and moralizing, universalizing religious systems is currently being pursued by the authors of this paper. For instance, we seek to ask whether a direct causal chain can be drawn from a society reaching a particular "level" of complexity and the adoption of many of the axial transformations discussed here, including the various institutional features discussed above. 


\section{Table 3. Summary of major questions for further research}

\begin{tabular}{l|l}
1 & Why did these developments occur when and where they did, given that there was no specific
\end{tabular} 'age' nor synchrony to axial transformations?

2 If similar, roughly synchronous developments in reflexive cognitive ability are meant to drive subsequent axial transformations, why do these changes not follow a common path in each area? Are there unaccounted for contributing factors that alter the shape of different experiences of axiality? If so, what?

Why do some regions experience axial transformations before the supposed arrival of these cognitive breakthroughs? Does this suggest that the cognitive developments highlighted by some Axial Age proponents - or at least their tangible manifestations - are really effects rather than causes of certain axial movements?

How should we contextualize the contributions of the handful of 'great men', the so-called sages who embody (if not inaugurate) axial reforms, given that there is wide variation in the number, timing, and content of the ideological traditions that can be associated with axial-type reforms?

What factors explain the wide variation seen in the moral foundations of complex societies around the globe, both in the past and the present?

How do we explain the so-called 'secondary breakthroughs' that gave rise to Christianity and Islam if not the eventual result of a highly-specific axial 'moment' in the eastern Mediterranean and Near East during the mid-first millennium BCE?

Crucially, what causal mechanism(s) can be proposed that can explain the wide variability in the way that the key axial traits rose and fell in different parts of the world? Is there one universal 'prime mover' that has driven the others throughout world history (e.g. cognitive ability universalizing ideologies) or do different factors facilitate axiality in different times/places? Or, is some third, as-yet unexplored factor the dominant causal force behind various axial-type transformations?

This may, in fact, help to clarify the unexpected variation seen in the adoption of the different cultural and institutional aspects of axial ideologies seen in the case studies found in the online supplement; different levels or specific combinations of the constituent elements of social complexity attained at different times in different areas could explain the historical patterns identified here. Alternatively, perhaps causality went in the opposite direction, where sociopolitical changes became codified in a society's prevailing ideological or even cognitive systems. Or there might have been another development, such as changes in the nature and intensity of inter-state warfare (Turchin et al. 2013, Turchin et al. 2015), shifts in the type of ritual activity being performed (Whitehouse et al. 2014), or the early arrival and development of productive agriculture (Collins et al. forthcoming, Currie et al. 2015, Johnson and Earle 2000) which intervened in this process as well. Further, we seek to uncover whether there is a causal connection between social complexity, moralizing religions, and measures of egalitarianism, including culturally- or legally-enforced differences between classes and claims of divinity made by rulers, as discussed here, as well as the practice of human sacrifice, slavery, and other markers of extreme social differentiation (Turchin et al. 2015).

Several Axial Age theorists have also raised the idea that the spread of literacy, numeracy, and increasingly complex record-keeping systems were a facilitating factor to axial transformations (Assmann 2012, Bellah 2011), a claim likewise in need of further scrutiny, especially now that these transformations can be properly disassociated from a particular historic period and localization. Another important idea requiring future research is that universalizing, moralizing religious systems evolved over long times due to certain evolutionary advantages that 
moralizing, norm-enforcing ideologies have over non-moralizing, 'archaic' religions (Norenzayan et al. 2016). As mentioned, the rise and continuing popularity of the major moralizing worldreligions highlighted by Axial Age proponents (esp. Christianity and Islam) need to be properly explained without relying on imprecise appeals to the heritage of earlier religious developments in Greece and the Levant.

Other important topics of future research include: whether rituals involving human sacrifice, another potential proxy for extreme inequality not explored here, tend to disappear during the first millennium BCE (Turchin 2012); whether large imperial formations became more or less common after the spread of moralizing religions and their universalizing ethos and whether the 'age of empires' precedes or follows the institutional reforms explored above (Bellah 2011, Eisenstadt 1986, Jaspers 1953); and if there is a specific link between urbanization and key Axial transformations (Bellah 2011, Jaspers 1953).

As we demonstrate here, a fruitful way to move forward is to extract specific scholastic claims and assess these claims against each other and against the empirical evidence systematically using a large amount of historical information from a diverse sampling pool. This approach makes it much easier to identify which ideas receive robust comparative historical support. Using the large body of historical material held by the Seshat: Global History Databank, we offer here a glimpse into how such a process looks in practice. It is our hope that future research by ourselves and others will continue to improve on the methodological rigor called for here to provide further clarification of these important issues and finally unlock the mysteries behind the foundations of complex societies. 
${ }^{1}$ See Turchin, Peter, Rob Brennan, Thomas Currie, Kevin Feeney, Pieter Francois, Daniel Hoyer, Joseph Manning, Arkadiusz Marciniak, Daniel Mullins and Alessio Palmisano. 2015. "Seshat: The Global History Databank." Cliodynamics: The Journal of Quantitative History and Cultural Evolution 6(1). for a detailed description of Seshat's sampling scheme and data coverage; also http://seshatdatabank.info/methods.

${ }^{2}$ See also Halton (2014).

${ }^{3}$ Throughout this article, we describe where historic events occurred in terms of the closest present-day country (India, China, etc.). This is done for the convenience of the reader, and follows most previous work on Axial Age. The developments we detail here occurred in past societies that were rarely, if ever, coterminous with their modern national counterparts.

${ }^{3}$ A forthcoming article by Purzycki et al., employing a detailed and systematic analysis of the connection between affluence and moralizing religions using ethnographic survey, make a compelling critique of Baumard et al.'s work and use of life-history theory. We thank Prof. Purzycki and team for allowing us to read an early version of that paper.

${ }^{4}$ E.g. recent articles in the Guardian, Wall Street Journal, Huffington Post, and New Statesman.

${ }^{5}$ Prosociality is, essentially, the ability of large groups of individuals in a society to work together for a common purpose. This working together is fundamental for societies to overcome external threats, get around problems of collective action, and develop systems and institutional structures that allow for (relatively) equitable treatment of all the society's members. Prosocial traits include things like trust and adherence to rules and manifests itself most clearly in terms of the cooperation between individuals or groups within a society; within social strata, between elite and non-elite, and between state agents and the general population. On this, see notably: Boyd and Richerson 2009; Turchin 2014; D. S. Wilson 2015.

${ }^{6}$ Stuart-Glennie, John Stuart. 1873. In the Morningland or The law of the origin and transformation of Christianity, Vol. 1: Longmans, Green, and Company., who was unknown to Jaspers, examines China, India, Israel-Palestine, and Greece.

${ }^{7}$ The independence of these cases has also come under doubt in recent years, as more is learned about the spread of goods, ideas, and people across Eurasia through the so-called Silk Road(s) and overseas routes traversing the Indian Ocean and Persian Gulf Beckwith, Christopher I. 2009. Empires of the silk road: A history of central Eurasia from the Bronze Age to the present: Princeton University Press, Frankopan, Peter. 2015. The silk roads: a new history of the world: Bloomsbury Publishing, Hansen, Valerie. 2012. The silk road: a new history: Oxford University Press, Heldaas Seland, Eivind. 2011. "The Persian Gulf or the Red Sea? Two axes in ancient Indian Ocean trade, where to go and why." World Archaeology 43(3):398-409..

${ }^{8}$ Indeed, for this reason areas outside of the Afro-Eurasian core (sub-Saharan Africa, Indonesia and Oceania, and North and South America) have never been part of the Axial Age story. For this reason, too, we overlook these regions here, though it is an interesting open question whether-and, if so, how and when - these other areas experienced similar, 'axial'-type transformations.

${ }^{9}$ Eg. Akhenaten, fourteenth century BCE (Joas 2012); Jesus, first century CE (Dalferth 2012); or Muhammed, seventh century CE (Casanova 2012).

${ }^{10}$ Egypt is, as mentioned, a contested case, though it has not been included in the most prominent accounts (e.g. Bellah 2011, Bellah and Joas 2012, Eisenstadt 1986a and 1986b, Jaspers 1953)

${ }^{11}$ Polity is defined as an independent political unit. Kinds of polities range from villages (local communities) through simple and complex chiefdoms to states and empires. What distinguishes a polity 
from other human groupings and organizations is that it is politically independent of any overarching authority; it possesses sovereignty.

${ }^{12}$ In accordance with the data-sharing policy of the ASA Code of Ethics (2007), the data used to generate this analysis will be made publicly available after completion of this project at http://dacura.scss.tcd.ie/seshat/. 


\section{REFERENCES}

Anđelković, Branislav. 2011. "Political organization of Egypt in the Predynastic period." Pp. $25-$ 32 in Before the Pyramids: The Origins of Egyptian Civilization, edited by E. Teeter. Oriental Institute of the University of Chicago.

Armstrong, Karen. 2006. The great transformation: The world in the time of Buddha, Socrates, Confucius and Jeremiah: Atlantic Books Ltd.

Arnason, Johann P., Shmuel N. Eisenstadt, and Björn Wittrock. 2005. "Introduction: History, Theory and Interpretation.” Pp. 15-18 in Axial Civilizations and World History, edited by J. P. Arnason, S. N. Eisenstadt, and B. Wittrock. Brill.

Arnason, Johann P., Armando Salvatore and Georg Stauth. 2006. "Introduction." Pp. 8-19 in Islam in Process. Historical and Civilizational Perspectives, edited by J. P. Arnason, A. Salvatore and G. Stauth. Transcript-Verlag.

Arnason, Johann P. 2012. "Rehistoricizing the Axial Age." Pp. 337-65 in The Axial Age and its Consequences, edited by R. N. Bellah and H. Joas. Harvard University Press.

Assmann, Jan. 2008. Of God and gods: Egypt, Israel, and the rise of monotheism: University of Wisconsin Press.

Assmann, Jan. 2012. "Cultural Memory and the Myth of the Axial Age." Pp. 366-407 in The Axial Age and Its Consequences, edited by R. N. Bellah and H. Joas. Harvard University Press.

Atran, Scott. 2016. "Moralizing religions: Prosocial or a privilege of wealth?" The Behavioral and brain sciences 39:e2. doi:10.1017/S0140525X15000321

Baines, John. 1995. "Origins of Egyptian Kingship." Pp. 95-156 in Ancient Egyptian Kingship, Vol. 9, edited by D. B. O'Connor and D. P. Brill.

Barnes, Michael H. 2009. Stages of thought: the co-evolution of religious thought and science: Oxford University Press.

Baskin, Ken and Dimitri M. Bondarenko. 2014. The Axial Ages of World History: Lessons for the 21st Century: ISCE Publishing.

Baumard, Nicolas and Pascal Boyer. 2013. "Explaining moral religions." Trends in Cognitive Sciences 17(6):272-80. doi: 10.1016/j.tics.2013.04.003.

Baumard, Nicolas, Alexandre Hyafil and Pascal Boyer. 2015. "What changed during the axial age: Cognitive styles or reward systems?" Communicative and Integrative Biology 8(5):1-3. doi: 10.1080/19420889.2015.1046657.

Baumard, Nicolas, Alexandre Hyafil, Ian Morris and Pascal Boyer. 2015. "Increased Affluence Explains the Emergence of Ascetic Wisdoms and Moralizing Religions." Current Biology 25(1):10-15. doi: http://dx.doi.org/10.1016/j.cub.2014.10.063.

Beard, Mary, John A. North and Simon Price. 1998. Religions of Rome, Vol. 1: Cambridge University Press.

Beckwith, Christopher I. 2009. Empires of the Silk Road: A history of central Eurasia from the Bronze Age to the present: Princeton University Press.

Bellah, Robert N. 1970. Beyond Belief: Essays on Religion in a Post-Traditional World: University of California Press.

Bellah, Robert N. 2005. "What is axial about the axial age?" Archives Européennes de Sociologie/European Journal of Sociology/Europäisches Archiv für Soziologie:69-89. 
Bellah, Robert N. 2011. Religion in Human Evolution: from the Paleolithic to the Axial Age: Harvard University Press.

Bellah, Robert N. and Hans Joas. 2012. The Axial Age and its Consequences: Harvard University Press.

Black, Antony. 2008. "The "Axial Period": What Was It and What Does It Signify?". Review of Politics 70(1):23.

Bottéro, Jean and André Finet. 2001. Ancient Mesopotamia: Everyday Life in the First Civilisation: Edinburgh University Press.

Boy, John D. and John Torpey. 2013. "Inventing the axial age: the origins and uses of a historical concept." Theory and Society 42(3):241-59. doi: 10.1007/s11186-013-9193-0.

Boy, John D. 2015. "The Axial Age and the Problems of the Twentieth Century: Du Bois, Jaspers, and Universal History." The American Sociologist 46(2):234-47.

Boyce, Mary. 1968. "The pious foundations of the Zoroastrians." Bulletin of the School of Oriental and African Studies 31(02):270-89.

Boyd, Robert, and Peter J. Richerson. "Culture and the Evolution of Human Cooperation."

Philosophical Transactions of the Royal Society of London B: Biological Sciences 364(1533): 3281-88.

Boyer, Pascal and Nicholas Baumard. 2016. "Projecting WEIRD features on ancient religions."

The Behavioral and brain sciences 39:23-24.

Briant, Pierre. 2002. From Cyrus to Alexander: a history of the Persian Empire: Eisenbrauns.

Bryce, Trevor. 2002. Life and Society in the Hittite World: OUP Oxford.

Cantera, Alberto. 2015. "Ethics." Pp. 313-32 in The Wiley Blackwell Companion to

Zoroastrianism, edited by Y. S.-D. V. M. Stausberg and A. Tessmann. John Wiley and Sons, Ltd.

Casanova, José. 2012. "Religion, the Axial Age, and Secular Modernity in Bellah's Theory of Religious Evolution." Pp. 192-221 in The Axial Age and its Consequences, edited by R. N. Bellah and H. Joas. Harvard University Press.

Clifford, Richard J. 1990. "Phoenician religion." Bulletin of the American Schools of Oriental Research (279):55-64.

Cobb, John B. 1979. The Structure of Christian Existence: Harper San Francisco.

Collins, Billie Jean. 2007. The Hittites and Their World (Archaeology and Biblical Studies):

Society of Biblical Literature.

Collins, Christian, Oluwole Oyebamiji, Neil R. Edwards, Philip Holden, Alice Williams, Greine Jordan, Daniel Mullins, Daniel Hoyer, Stephanie Grohman, Patrick E. Savage, Gavin MendelGleason, Kevin Feeney, Pieter François, Harvey Whitehouse, Peter Turchin, and Thomas Currie. Forthcoming. "Estimating agricultural productivity and carrying capacity in past societies: A method combining palaeoclimatic crop models and historical \& archaeological information."

Coningham, Robin. 2001. "The archaeology of Buddhism." Archaeology and world religion: 6195.

Cornell, Tim J. and Katheryn Lomas. 2003. "Coriolanus: myth, history and performance." Pp. 73-97 in Myth, History and Culture in Republican Rome, Studies in Honour of TP Wiseman, 
edited by David Braund, Christopher Gill, and Timothy Peter Wiseman. University of Exeter Press.

Currie, T. E., Amy Bogaard, Rudolf Cesaretti, Neil R. Edwards, Pieter Francois, Philip Holden, Daniel Hoyer, et al. 2015. "Agricultural Productivity in Past Societies: Toward an Empirically Informed Model for Testing Cultural Evolutionary Hypotheses." Cliodynamics: The Journal of Quantitative History and Cultural Evolution 6(1):24-56. doi: https://doi.org/https://escholarship.org/uc/item/4h29270b.

Dalferth, Ingolf U. 2012. "The Idea of Transcendence." Pp. 146-88 in The Axial Age and its Consequences, edited by R. N. Bellah and H. Joas. Harvard University Press.

DeCaroli, Robert. 2004. Haunting the Buddha: Indian popular religions and the formation of Buddhism: Oxford University Press.

Diuk, Carlos, Diego Fernandez Slezak, Iván Raskovsky, Mariano Sigman, and Guillermo Cecchi. 2012. "A Quantitative Philology of Introspection," Frontiers in Integrative Neuroscience 6/80. doi: 10.3389/fnint.2012.00080.

Eisenstadt, Shmuel N. 1986a. "The Axial Age Breakthroughs: Their Characteristics and Origins." Pp. 1-28 in The Origins and Diversity of Axial Age Civilizations, SUNY series in Near Eastern studies, edited by S. N. Eisenstadt. SSUNY Press.

Eisenstadt, Shmuel N. 1986b. "Introduction: The Axial Age Breakthrough in Ancient Greece," Pp. 29-39 in The Origins and Diversity of Axial Age Civilizations, edited by S. N. Eisenstadt. SSUNY Press.

Eisenstadt, Shmuel N. 1996. Japanese Civilization: a comparative view: The University of Chicago Press.

Eisenstadt, Shmuel N. 2005. "Axial Age Civilization and the Axial Age Reconsidereda." in Axial Civilizations and World History, edited by J. P. Arnason, S. N. Eisenstadt and B. Wittrock. Brill.

Eisenstadt, Shmuel N. 2012. "The Axial Conundrum between Transcendental Visions and Vicissitudes of Their Institutionalizations: Constructive and Destructive Possibilities." Pp. $277-$ 93 in The Axial Age and its Consequences, edited by R. N. Bellah and H. Joas. Harvard University Press.

Elkana, Yehuda. 1986. "The emergence of second-order thinking in classical Greece." Pp. 40-64 in The Origins and Diversity of Axial Age Civilizations, edited by S. N. Eisenstadt. SSUNY Press.

Faulkner, Raymond, Ogden Goelet, Carol Andrews and James Wasserman. 2008. The Egyptian Book of the Dead: The Book of Going Forth by Day-The Complete Papyrus of Ani Featuring Integrated Text and Full-Color Images: Chronicle Books.

Ferguson, John. 2016. Moral Values in the Ancient World: Routledge.

Finer, Samuel. 1999. The History of Government. Vol. I: Ancient Monarchies and Empires: Oxford University Press.

Finley, Moses I. 2002. "The silent women of Rome." Pp. 147-60 in Sexuality and Gender in the Classical World: Readings and Sources, edited by L. K. McClure. Blackwell Publishers.

Francois, Pieter, J.G. Manning, Harvey Whitehouse, Rob Brennan, Thomas Currie, Kevin Feeney and Peter Turchin. 2016. "A Macroscope for Global History: Seshat Global History 
Databank, a methodological overview." Digital Humanities Quarterly 10(4). doi:

http://www.digitalhumanities.org/dhq/vol/10/4/000272/000272.html

Frankopan, Peter. 2015. The Silk Roads: a new history of the world: Bloomsbury Publishing.

Goldman, Leon. 2012, "Women II: In the Avesta" Encyclopcedia Iranica, online edition.

Retrieved 19 May, 2016 (http://www.iranicaonline.org/articles/women-ii-avesta).

Grenet, Frantz. 2015. "Zarathustra's Time and Homeland: Geographical Perspectives." Pp. 21-31 in The Wiley Blackwell Companion to Zoroastrianism, edited by M. Stausberg, Y. S. D.

Vevaina and A. Tessmann. John Wiley \& Sons, Ltd.

Habermas, Jürgen. 2010. An Awareness of What is Missing: Faith and reason in a post-secular age: Polity.

Halton, Eugene. 2014. From the axial age to the moral revolution: John Stuart-Glennie, Karl Jaspers, and a new understanding of the idea: Springer.

Hansen, Valerie. 2012. The Silk Road: a new history: Oxford University Press.

Harris, Ian. 2008. Cambodian Buddhism: history and practice: University of Hawaii Press.

Heldaas Seland, Eivind. 2011. "The Persian Gulf or the Red Sea? Two axes in ancient Indian

Ocean trade, where to go and why." World Archaeology 43(3):398-409.

Hick, John. 2004. An Interpretation of Religion: Human responses to the transcendent: Yale University Press.

Higham, Charles. 2014. Early Mainland Southeast Asia: from first humans to Angkor. River Books.

Hinds, K. 2006. The Pharaoh's Court: Marshall Cavendish.

Hoffner, H.A. 2006. "The Royal Cult in Hatti." Pp. 132-51 in Text, Artefact and Image:

Revealing Ancient Israelite Religion, edited by G. B. a. T. Lewis. Brown Judaic Studies.

Hsu, Cho-yun. 1999. "The Spring and Autumn Period." Pp. 545-86 in The Cambridge History of Ancient China: From the Origins of Civilization to 221 BC, edited by M. Loewe and E. L. Shaughnessy. Cambridge University Press.

Jaspers, Karl. 1948. "The Axial Age of Human History." Commentary 6:430.

Jaspers, Karl. 1949. Vom Ursprung und Ziel der Geschichte. Zurich: Artemis-Verlag Zurich.

Jaspers, Karl. 1953. The Origin and Goal of History: Yale University Press.

Joas, Hans. 2012. "The Axial Age Debate as Religious Discourse." Pp. 9-29 in The Axial Age and its Consequences, edited by R. N. Bellah and H. Joas. Harvard University Press.

Johnson, Allen W., and Timothy K. Earle. 2000. The Evolution of Human Societies: From Foraging Group to Agrarian State. Stanford University Press.

Kant, Anjani. 2003. Women and the Law: APH Publishing.

Keightley, David N. 1999. "The Shang: China’s First Historical Dynasty." Pp. 232-91 in

The Cambridge History of Ancient China: From the origins of civilization to 221, edited by M.

Loewe and E. L. Shaughnessy. Cambridge University Press.

Keightley, David N. 2004. "The Making of the Ancestors: Late Shang Religion and Its Legacy." Pp. 3-63 in Religion and Chinese Society, Vol. 1, edited by J. Lagerway: Chinese University Press. 
Kemp, Barry J. 1983. "Old Kingdom, Middle Kingdom and Second Intermediate Period C. 2686-1552 BC," Pp. 71-182 in Ancient Egypt: A Social History, edited by B. G. Trigger, B. J. Kemp, B. J. O’Connor and D. Lloyd. Cambridge University Press.

Kuhrt, Amelie. 2001. "The Achaemenid Persian empire (c. 550-c. 330 BCE): Continuities, adaptations, transformations." Pp. 93-123 in Empires: Perspectives from Archaeology and History, edited by S. E. Alcock, T. N. D’Altroy, K. D. Morrison, and C. M. Sinopoli. Cambridge University Press.

Lamotte, Étienne. 1988. History of Indian Buddhism: from the origins to the Saka era: Université catholique de Louvain, Institut orientaliste.

Larson, Jennifer. 2016. Understanding Greek Religion: Routledge.

Lasaulx, Ernst von. 1856. Neuer Versuch einer alten auf die Wahrheit der Thatsachen gegründeten Philosophie der Geschichte: J.G. Cotta.

Lendon, Jon E. 2001. Empire of Honour: The Art of Government in the Roman World: Oxford University Press.

Lewis, Mark E. 1999. "Warring States Political History." Pp. 587-650 in The Cambridge History of Ancient China: From the origins of civilization to 221 BC, edited by M. Loewe and E. L. Shaughnessy. Cambridge University Press.

Lewis, Mark E. 2007. The Early Chinese Empires: Qin and Han: Harvard University Press.

Liverani, Mario 2014. The Ancient Near East: History, Society and Economy. S. Tabatabai (trans.): Routledge.

Lizardo, Omar. 2016. "A Collective Object for the Sociology of Morality Project." Contemporary Sociology 45(2):125-129.

Llewellyn-Jones, Lloyd. 2013. King and Court in Ancient Persia: Edinburgh University Press.

Loewe, Michael. 1986. "The Religious and Intellectual Background." Pp. 649-725 in The Cambridge History of China, Vol. 1, edited by D. Twitchett and M. Loewe. Cambridge University Press.

Macuch, Maria. 2015. "Law in Pre-Modern Zoroastrianism." Pp. 289-98 in The Wiley-Blackwell Companion to Zoroastrianism, edited by M. Stausberg and Y. Sohrab-Dinshaw Vevaina. Wiley Blackwell.

Mahmoudi, Hoda. 2008. "The Permanence of Change: Contemporary Sociological and Bahá'í Perspectives on Modernity." The Journal of Baha'i Studies 18(1-4):41-76.

Malandra, William W. 1983. An Introduction to Ancient Iranian Religion: Readings from the Avesta and Achaemenid inscriptions, Vol. 2: University of Minnesota Press.

Mikalson, Jon D. 2006. "Greek Religion: Continuity and Change in the Hellenistic Period," Pp. 208-22, in The Cambridge Companion to the Hellenistic World, edited by G. R. Bugh. Cambridge University Press.

Miksic, John N. 2007. Historical dictionary of ancient Southeast Asia: Scarecrow Press. Momigliano, Arnaldo. 1975. Alien Wisdom: the limits of Hellenization: Cambridge University Press.

Morris, Ian. 2010. Why the West Rules-For Now: The patterns of history and what they reveal about the future: Profile books. 
Mota, Natalia B., Sylvia Pinheiro, Mariano Sigman, Diego Fernandez Slezak, Guillermo Cecchi, Mauro Copelli, and Sidarta Ribeiro. 2016. "The Ontogeny of Discourse Structure Mimics the Development of Literature." arXiv Preprint:1612.

Mumford, Lewis. 1956. The Transformations of Man: Harper and Row.

Noll, Kurt L. 2007. "Canaanite Religion." Religion Compass 1(1):61-92.

Noreña, Carlos. 2010. "The Early Imperial Monarchy," Pp. 533-546 in The Oxford handbook of Roman studies, edited by A. Barchiesi and W. Scheidel. Oxford University Press.

Norenzayan, Ara, Azim F. Shariff, Will M. Gervais, Aiyana K. Willard, Rita A. McNamara, Edward Slingerland, and Joseph Henrich. 2016. "The cultural evolution of prosocial religions." Behavioral and Brain Sciences 39. doi: 10.1017/S0140525X14001356.

O'Connor, David. 1983. "New Kingdom and Third Intermediate Period 1552-664 BC." Pp. 183278 in Ancient Egypt: A Social History, edited by B. G. Trigger, B. J. Kemp, D. O'Connor and A. B. LLoyd. Cambridge University Press.

Orlin, Eric. 2007. "Urban Religion in the Middle and Late Republic." Pp. 58-70 in A Companion to Roman Religion, edited by J. Rüpke. Blackwell.

Picken, Stuart D. B. 2010. Historical Dictionary of Shinto: Scarecrow Press.

Provan, Iain. 2013. " Convenient Myths: The Axial Age, Dark Green Religion, and the World That Never Was: Baylor University Press.

Puett, Michael. 2002. "Humans and Gods: The theme of self-divinization in early China and early Greece." Pp. 55-74 in Early China/Ancient Greece: Thinking through comparisons, edited by Steven Shankman, Stephen W. Durrant. SUNY Press.

Purzycki, Benjamin G., Cody T. Ross, Coren Apicella, Quentin D. Atkinson, Emma Cohen, Rita Anne McNamara, Aiyana K. Willard, Dimitris Xygalatas, Ara Norenzayan, Joseph Henrich. Forthcoming. "Material security, life history, and moralistic religions: A cross-cultural examination."

Rose, Jenny. 2015. "Gender." Pp. 273-88 in The Wiley-Blackwell Companion to Zoroastrianism, edited by M. S. a. Y. S.-D. Vevaina: Wiley Blackwell.

Runciman, W. G. 2012. "Righteous Rebels: When, Where, and Why?" Pp. 317-34 in The Axial Age and its Consequences, edited by R. N. Bellah and H. Joas. Harvard University Press.

Scheid, John. 2011. "Graeco-Roman Cultic Societies." Pp. 535-547 in The Oxford Handbook of Social Relations in the Roman World, edited by M. Peachin. Oxford University Press.

Schmidt-Leukel, Perry. 2006. Understanding Buddhism: Dunedin Academic Press Ltd.

Schmitt, Rüdiger. 1983. “Achaemenid Dynasty,” Encyclopaedia Iranica 4(1):414-26.

Schwartz, Benjamin I. 1975. Wisdom, Revelation, and Doubt: Perspectives on the first millennium BC: Daedalus.

Shahar, Meir and Robert Paul Weller. 1996. Unruly Gods: Divinity and society in China: University of Hawaii Press.

Shaked, Shaul. 1998, "Eschatology i: In Zoroastrianism and Zoroastrian Influence." Encyclopoedia Iranica, online edition. Retrieved 19 May, 2016 (http://www.iranicaonline.org/articles/women-ii-avesta).

Skjærvø, Prods O. 2014. "Achaemenid Religion." Religion Compass 8(6):175-87. 
Smith, Andrew. 2015. "Between Facts and Myth: Karl Jaspers and the actuality of the axial age." International Journal of Philosophy and Theology 76(4):315-34.

Spencer, Herbert. 1892. The Study of Sociology, Vol. 5: Kegan Paul, Trench, Trübner and Company.

Stein, Burton. 2010. A History of India, Vol. 10: John Wiley \& Sons.

Stets, Jan E. and Michael J. Carter. 2012. "A Theory of the Self for the Sociology of Morality." American Sociological Review 77(1):120-40. doi:10.1177/0003122411433762.

Stroumsa, Guy G. 2012. "Robert Bellah on the Origins of Religion: A Critical Review." Revue De L'Histoire Des Religions 229(4):467-77.

Stuart-Glennie, John Stuart. 1873. In the Morningland or The law of the origin and transformation of Christianity, Vol. 1: Longmans, Green, and Company.

Takaeshi, Matsumae. 1993. "Early Kami Worship." Pp. 317-58 in The Cambridge History of Japan. Vol. 1: Ancient Japan, edited by D. Brown. Cambridge University Press.

Tang, Yijie. 2016. Anthology of Philosophical and Cultural Issues: Springer.

Taylor, Charles. 2009. A Secular Age: Harvard University Press.

Teeter, Emily. 2011. Religion and Ritual in Ancient Egypt: Cambridge University Press.

Thapar, Romila. 2003. "History as Politics." India Together (May).

Turchin, Peter. 2008. "Arise 'cliodynamics'." Nature 454(7200):34-35.

Turchin, Peter. 2011. "Toward Cliodynamics-an Analytical, Predictive Science of History." Cliodynamics 2(1). doi: http://escholarship.org/uc/item/82s3p5hj.

Turchin, Peter. 2012. "Religion and empire in the Axial Age." Religion, Brain \& Behavior 2(3):256-60.

Turchin, Peter, Harvey Whitehouse, Pieter Francois, Edward Slingerland and Mark Collard. 2012. "A Historical Database of Sociocultural Evolution." Cliodynamics: The Journal of Theoretical and Mathematical History 3(2). doi: http://escholarship.org/uc/item/2v8119hf.

Turchin, Peter, Thomas Currie, EAL Turner and Sergey Gavrilets. 2013. "War, Space, and the Evolution of Old World Complex Societies." Proceedings of the National Academy of Sciences (110):16384-89.

Turchin, Peter. 2015. Ultrasociety: How 10,000 Years of War Made Humans the Greatest Cooperators on Earth: Berets Books.

Turchin, Peter. 2014. "Cultural Evolution and Cliodynamics." Cliodynamics: The Journal of Quantitative History and Cultural Evolution 5(1). doi: https://doi.org/10.21237/C7clio5125308.

Turchin, Peter, Rob Brennan, Thomas Currie, Kevin Feeney, Pieter Francois, Daniel Hoyer, Joseph Manning, Arkadiusz Marciniak, Daniel Mullins and Alessio Palmisano. 2015. "Seshat: The Global History Databank." Cliodynamics: The Journal of Quantitative History and Cultural Evolution 6(1). doi: https://doi.org/10.21237/C7clio6127917

Uhalde, Kevin. 2012. "Justice and Equality." Pp. 764-79 in The Oxford Handbook of Late Antiquity, edited by S. F. Johnson. Oxford University Press.

Van Dijk, Jacobus. 2000. "The Amarna Period and the Later New Kingdom (c. 1352-1069 BC)." Pp. 272-313 in The Oxford History of Ancient Egypt, edited by I. Shaw. Oxford University Press. 
Vickery, Michael. 1986. "Some remarks on early state formation in Cambodia." Pp. 95-115 in Southeast Asia in the 9th to 14th Centuries, edited by David G. Marr, Anthony Crothers Milner. Institute of Southeast Asian Studies.

Voegelin, Eric. 1974. Order and History, Vol. 4: Lousiana State University Press.

Wagner, Peter. 2005. "Palomer's Question." 87-106 in Axial Civilizations and World History, edited by J. Arnason, S. N. Eisenstadt, and B. Wittrock. Brill.

Webb, Adam K. 2015. Deep Cosmopolis: Rethinking World Politics and Globalization: Routledge.

Weber, Alfred. 1935. Kulturgeschichte als Kultursoziologie: Sijthoff.

Weber, Max. 1978[1922]. Economy and Society: An outline of interpretive sociology, 2., Vol. 2: University of California Press.

Whaling, Frank. 2009. Understanding Hinduism: Dunedin.

Whitehouse, Harvey. 2012. "Cognition, evolution and the future of social anthropology." Pp. 234-42 in The SAGE handbook of Social Anthropology, Vol. 2, edited by R. Fardon, O. Harris, T. H. J. Marchand, M. Nuttal, C. Shore, V. Strang and R. A. Wilson. SAGE Publications Ltd.

Whitehouse, Harvey, Jonathan A Lanman, Greg Downey, Leah A Fredman, William B Swann Jr, Daniel H Lende, Robert N McCauley, David Shankland, Michael Stausberg and Dimitris Xygalatas. 2014. "The Ties That Bind Us: Ritual, fusion, and identification." Current Anthropology 55(6): 674-695. doi: https://doi.org/10.1086/678698.

Whitehouse, Harvey, Pieter François, Patrick E. Savage, Thomas E. Currie, Kevin C. Feeney, Enrico Cioni, Rosalind Purcell, et al. Forthcoming. "Complex Societies and Routinised Rituals Precede Moralising Gods throughout World History."

Wilfong, Terry G. 2010. "Gender in Ancient Egypt." Pp. 164-79 in Egyptian Archaeology, edited by W. Wendrich. Wiley-Blackwell.

Wilson, David Sloan. 2015. Does Altruism Exist?: Culture, Genes, and the Welfare of Others: Yale University Press.

Wittrock, Björn. 2012. "The Axial Age in Global History: Cultural Crystallizations and Societal Transformations." Pp. 102-25 in The Axial Age and Its Consequences, edited by R. N. Bellah and H. Joas. Harvard University Press.

Wittrock, Björn. 2015. "The Axial Age in World History." Pp. 101-19 in The Cambridge World History, edited by Craig Benjamin. Cambridge University Press.

Yazdani, Naveed and Hasan S. Murad. 2015. "Toward an Ethical Theory of Organizing." Journal of Business Ethics 127(2):399-417. doi: 10.1007/s10551-014-2049-3.

Zhao, Suisheng. 2005. "China's Pragmatic Nationalism: is it manageable?". The Washington Quarterly 29(1):131-44. 
ONLINE SUPPLEMENTAL MATERIALS: ANALYTICAL SUMMARIES OF THE AVAILABLE HISTORICAL DATA FOR 10 CASES SURVEYED

\section{Part 1: Analytical summaries for five conventional axial regions}

1. GREECE While a lack of clear evidence concerning some of the proxies before $1000 \mathrm{BCE}$ restricts determining precisely how early these traits may have appeared, our survey of the evidence reveals that universalizing, moralizing ideological traditions and their cultural and institutional manifests did not emerge initially in Greece during the traditional bounds of the Axial Age ( 800 BCE to $200 \mathrm{BCE})$. Many of the key traits were in place before this period and the region was subject to influence from several other important societies in the Near and Middle East, undermining the idea of spontaneous, independent axial flourishing. Contrarily, the region certainly did witness the emergence and popularization of novel ideological schools stressing moral and egalitarian principles along with a host of institutional reforms over a long course of time.

What is today Greece was, in the first millennium BCE, a politically fragmented region, featuring numerous small, largely independent city-states. These city-states did share many important cultural features, notably a common language and a shared set of religious practices, customs, and thoughts about the gods. This 'traditional' Greek religion focused on the proper ritual activity needed to appease various supernatural beings (each city-state focussed on different gods, though the pantheon was common). No evidence suggests that this religious ideology stressed universalizing or moralizing precepts in any significant way. Greek gods were certainly not omniscient and, crucially, did not much care about what Greek people did from a moral standpoint, provided only that they continued to participate in the proper rituals. Nor was there any widespread punishment for moral transgressions; proxies 1,2, and 4, in other words, remained absent in the region throughout the first millennium BCE. Interestingly, there is clear evidence for the promotion of prosociality (proxy 3); though this appears to be the result of civic institutions and a wider socio-political culture in several Greek city-states during the mid-first millennium BCE, rather than a result of any novel moralizing ideology developing during this period (Larson 2016, Mikalson 2006).

Several important philosophical traditions did develop in Greece during the latter half of the first millennium BCE-from Platonic-Socratic and Aristotelian thought to Stoicism and Epicureanism (Beard, North and Price 1998, Ferguson 2016, Larson 2016, Mikalson 2006, Orlin 2007). These philosophical schools expressed strong moralizing and egalitarian traits. Notably in Aristotelian, Stoic, and Epicurean thought there were claims for establishing a universalizing frame of reference for physical and metaphysical inquiry. Indeed, it is these philosophies, with their cosmology downplaying the role and anthropomorphic nature of deities and metaphysics stressing common origins and ethical imperatives for all people, that have led many Axial Age proponents to include Greece as one of the axial regions (Bellah 2011, Jaspers 1953). Linked with this is the idea that Greek rulers (whether ruling democratic, oligarchic, or tyrannical city-states) typically claimed no special divine sanction for themselves (proxy 5). However, this seems to have developed already by the early Iron Age, well before the birth of the region's axial sages. While these philosophical ideologies became important with the elite in some of the Greek city-states and particularly through their later adoption by many prominent Romans 
(Scheid 2011), they were never the dominant ideology among the general population in ancient Greece or Rome. These traditions existed alongside of, and never came close to replacing, traditional religious thought and practice (Mikalson 2006).

Moreover, although the universalizing metaphysics of these philosophical ideals paved the way for future claims about the 'equality' of people under god (Larson 2017 pers. comm.; Uhalde 2012), this did not translate into egalitarian institutions during the Greek Classical period (5th-4th centuries BCE). Legal and social differentiation between males and females, elites and non-elites was not only tolerated, but justified. Proxies 6-7 and 9-12, thus, remained absent in the region throughout the Axial period. Interestingly, many poleis saw the codification and regularization of law during the first millennium, and the Classical era (mid-first millennium BCE) saw major advances in judicial and administrative systems as well as the famous democratizing reforms of Classical Athens (proxies 8-12).

2. ISRAELPALESTINE
The region known in antiquity as the Levant (modern-day Israel, Palestine, Lebanon, and parts of Syria and Jordan) features prominently in several works on the Axial Age due to the presence of early Hebrew prophets (e.g. Bellah 2011, Eisenstadt 1986a, Jaspers 1953, M. Weber 1978[1922]). The region is a troubling case, however, as it cannot be understood as an isolated, independent region, which has often been recognized (Bellah 2011:270). What this means for the its role in the Axial Age, then, is that it is not sufficient to analyze one religious-ideological tradition in isolation, such as Judaism as it was developed and articulated here (and elsewhere) throughout the first millennium $\mathrm{BCE}$, though this is how the region is typically treated. What matters for the idea of an 'Axial Age' as a unique, identifiable, and important historical reality is the rise in a particular region and time of certain traits and innovative ideas, where they did not previously exist. In Israel-Palestine, the dominance of Egyptian and Phoenician states in the region from the mid- to latesecond millennium BCE (Assmann 2012, Clifford 1990, O'Connor 1983, Teeter 2011, Van Dijk 2000) requires us to explore the presence of moralizing, universalizing, and egalitarian ethics in the ideologies of these polities. Critically, nearly all of the key proxies $(1-9,11)$ were present in the area before the traditional Axial Age period.

It is clear to see how the idea of the Levant as an Axial region developed. During the Axial period, Judaic ideology in the region seems to have emphasized many of the traits associated with axiality, including an explicit moral stance, a clear stress on the omniscience and omnipresence of the chief deity, reinforcement of prosociality, and claims about the equality of all people under the eyes of god (Finer 1999, Noll 2007). Further, Persian and Babylonian influence in the region during the Axial Age helped spread Zoroastrian ideals to the Levant (and into Turkey and Greece, for that matter), which also carried many elements of a universalizing and moralizing ethic, including the idea that rulers were not gods, which was indeed a change from earlier periods (notably under Egyptian control of the region). It is difficult, then, to conclude that the transformations experienced in the Levant were novel, autochthonous developments during the Axial Age. Even the Judaic ideals of the time were at the very least heavily influenced by earlier traditions, arguing for a different reading of the region's role in the spread of axiality.

The region's institutional systems are likewise complicated by its imperial history. The Levant was not an 'island of light', to use Jaspers' phrase, but was subject to the 
legal and political structures of the many imperial states that occupied the over the course of history, from Egyptians to Neo-Assyrians and Neo-Babylonians to Achaemenids and Seleucids and then Romans. These states featured fairly welldeveloped institutions, including legal and administrative apparatus (Hinds 2006, Lendon 1997, Liverani, 2011, Schmidt 1983). It was, arguably, their advanced sociopolitical makeup that allowed each to become vast imperial powers to begin with. This again undermines the causal chain put forward by many axial scholars, demonstrating that advanced institutional systems were in force in the region before any putative cognitive, ideological, and religious transformations took place. Interestingly, too, the imperial states that occupied the Levant before and during the traditional Axial Age period did not have very strong constraints on their rulers (Baines 2017 pers. comm., Llewellyn-Jones 2013, Noreña 2010) suggesting that this aspect of axiality may not be as strongly related to others, or at least that the Levant is not the typical 'core' case it is normally presented to be.

3. INDIA The history of South Asia is perhaps most supportive of the Axial Age idea in its typical articulation. Lack of high-quality, reliable historical information for the late second-early first millennium BCE, however, makes it difficult to assess just how 'novel' the supposedly axial developments were during the mid-first millennium, and it may have been the case that many of these traits were present in the region in earlier periods, as was the case in Israel-Palestine.

The rise of Buddhism after the birth of the Gautama Buddha in eastern India sometime in the mid-first millennium BCE and its fast spread throughout the subcontinent leading to its official support as a 'state ideology' under the Mauryan rulers (ca. 324-185 BCE), does indeed coincide with the traditional explication of the Axial Age (Thapar 2003, 2012). Buddhism was, and remains, a religious system quite concerned with moral behavior, including a strong emphasis on prosocial activity between co-religionists (proxies 2-3) (DeCaroli 2004, Lamotte 1988, Schmidt-Leukel 2006, Thapar 2003). It is likely for this reason that Buddhism is often highlighted as one of the primary Axial ideologies. Further, Buddhist thought clearly denied divinity to its rulers (proxy 5), although Mauryan rulers from the time of Asoka (r. 268-232 BCE) certainly legitimated their rule in part based on their preservation and support for religious ideals (Coningham 2017 pers. comm., Stein 2010). Nor should the supernatural beings associated with Buddhist thought be considered omniscient in several important ways (proxy 4) (Schmidt-Leukel 2006). It is unclear the extent to which punishments for transgressions (proxy 1) at the time were 'religious' and moral, or whether they were functions of the state's judicial authority, as state support for Buddhist morality conflated the two areas (SchmidtLeukel 2006, Wallace 2017 pers. comm.). Buddhism also is notable for its very clear insistence on social egalitarianism. It is committed to the ideal that all people can attain the enlightenment achieved by Gautama Buddha himself, regardless of class, ethnicity, etc. On the other hand, despite its universalizing morality and egalitarianism, early Buddhist thought did support and justify distinctions between rulers and those ruled (proxies 6-7); these measures fluctuate through the first millennium BCE as contrasting ideals, legal regulations, and political realities complicate any clear trends towards increasing egalitarianism.

Another important consideration about South Asia during the Axial Age is that, like Israel-Palestine, several different powerful states occupied different portions of the region at different times. Some local states expanded throughout the subcontinent, 
while other 'external' powers claimed portions of the region, particularly in the Northwest. This undermines the identification of anything like an 'Indian' society at this time, let alone an autochthonous Indian axial transformation. The appearance, for instance, in the Kachi Plain region around modern-day Pakistan of powerful states from Iran (Achaemenids, later Parthians) and Greco-Macedonia (Alexander the Great's Empire, Greco-Bactrian Kingdom) brought new ideologies into South Asia, which were present alongside, and mixed to some degree with, Buddhist thought. Further complicating this picture is that Buddhism itself, as mentioned, arose on the back of Hinduism and existed alongside Hinduism and Jainism through much of the first millennium. Still, the emphasis by many Axial Age proponents on 'Great Men,' particularly Gautama Buddha himself and his followers, as the agents of axial transformations does not mesh well with the diverse, heterodoxic reality of the period. Unfortunately, it is difficult to reconstruct the contents of Hindu ideology in the early first millennium BCE, making it impossible to evaluate whether the moralizing of Buddhism, Hinduism, and Jainism was a new development of the midfirst millennium $\mathrm{BCE}$ or an inheritance from earlier practice.

4. IRAN

The dominant religious ideology that comes to us from ancient Persia is Zoroastrianism, the only of the main Axial religions that is not practiced in large numbers today and, in part as a consequence, the least well understood. Most of what is known about Zoroastrianism comes from the Achaemenid Empire (559-331 BCE), which is fairly well-attested historically and archaeologically. This is right in the heart of the conventional Axial Age, leading Zoroastrianism, and the sage Zoroaster, to be often counted among the main Axial movements. Indeed, the Zoroastrianism known from the first millennium BCE presents clear evidence for many of the key aspects of axiality emphasized by various scholars: Achaemenid Zoroastrian practice espoused a universal morality with an emphasis on individual responsibility for securing one's own fate; the chief deity, Ahura Mazda, was thought of as having something like omniscience; and prosociality was stressed, leading to widespread public goods production (notably temples, roads, irrigation works) (proxies 2-4) (Boyce 1968, Cantera 2015, Skjærvø 2014). Further, Achaemenid rulers, despite the propaganda of certain contemporary Greek historians, were not god-kings (proxy 5) in the way other ancient rulers were (e.g. Egyptian pharaohs; see below) (Kuhrt 2001). As with Buddhism under the Mauryans, there is some evidence that Zoroastrianism proscribed punishments for certain moral transgressions (proxy 1), but it is difficult to disentangle religiously motivated punishment from politically motivated ones by the Achaemenid elite (Malandra 1983). Moreover, the extension of Achaemenid rule from its heartland in the Iranian plateau into Central Asia, Northwestern India and Pakistan, as well as West into Anatolia, the Levant, and becoming an important force in the East Mediterranean helped spread these ideals at the end of the first millennium BCE. This highlights Zoroastrianism as a key ideology supporting the Axial thesis, though its spread further complicates the picture of the supposedly Axial regions as unique, isolated developments.

Although Achaemenid-era Zoroastrianism seems to have espoused many axial elements, there are other facets of Zoroastrianism that contradict this picture. Notably, while Zoroastrianism espoused a strong egalitarian ethic, in practice it was used to justify various social, political, and legal inequalities throughout the Empire (proxies 6-7), for instance differentiating Achaemenid rulers from the rest of the population (Goldman 2012, Shaked 1998). Only in the Hellenistic period with their 
Greco-Macedonian influence did the region see institutional reforms reinforcing a more universal application of norms and regulations (Larsen 2017, pers. comm.). Further, as noted above, the Achaemenid state sported a well-developed institutional apparatus, with clear legal regulations and administrative procedures (proxies 8-9, 11), though without providing significant constraints on the authority of rulers (Liverani, 2011, Llewellyn-Jones 2013, Schmidt 1983). A further complication is that little is known about pre-Achaemenid Zoroastrianism, but there are hints that the ideology, or close precursors, were present from late Bronze Age. In fact, Bellah (2011:271), while acknowledging the great influence Persian ideology had on other developments in Eurasia, chose to remove Zoroastrianism from his study of Axial religions on the grounds that its origins were simply too opaque. This makes it difficult to support the claim that Zoroastrianism should be considered an axial ideology, or that Iran should feature as a typical, independent, and autochthonous axial region (cf. the Levant above). In fact, the little that is known about Akkadian, Assyrian, Elamite, and Babylonian ideologies present in the region during the early first millennium BCE support a reading of a wider, earlier 'axial' type transformation throughout the Near East. The Akkadian Šruru, for example, a liturgy compiled likely in the late second millennium BCE from earlier material, describes clear legal and moral 'sins' to be avoided, a suggestion of a moralizing ideology long before the Achaemenid Axial Age (Bidmead 2017 pers. comm., Bottéro and Finet 2001).

5. CHINA

Like Israel-Palestine and, to a lesser extent, Iran and India, China was subject to political disunity throughout much of the first millennium BCE and 'foreign' influence thereafter. The 'great axial sage' native to China typically singled out is Confucius, a moralizing religious philosopher who lived during the Spring Autumn period of Chinese history, a period characterized by intense inter-state warfare (Hsu 1999). As with the other supposedly Axial regions, China and Confucianism display some of the key traits associated with a universalizing moralizing ideology, but other important traits contradict the Axial thesis and the precise temporal and geographic scope of the predicted axial transformations in the region remain unclear.

Confucianism, in antiquity and more recent iterations, is strongly associated with ideas about moralistic judgement as well as promoting moralizing precepts and exhortations to prosocial activity (proxies 1-3) (Lewis 2007, ter Haar 2017 pers. comm.). This was accompanied with some universalizing and egalitarian ideals, such as espousing a common, universal moral code applicable to all people (ter Haar 2017 pers. comm.). However, it is also clear that at least through the first millennium BCE Confucian philosophy supported strong hierarchical distinctions between ruler, elites, and the general population (proxies 6-7), and distinguished between male and female and old and young, in analogy with the hierarchies of a 'proper' Confucian family (Puett 2002, Zhao 2005). Most significantly, the chronology of Confucianism's spread throughout China does not line up with the traditional Axial Age timeline. Confucianism itself, though traced back to its eponymous founder in the mid-first millennium BCE, did not become the dominant, state-supported nor widely popular ideology in what is today China until much later, with the rise of the Han Empire around the turn of the first millennium $\mathrm{CE}$ at the earliest. This puts Confucian developments at best at the very outer boundary of the conventional Axial Age periodization, perhaps a candidate as a 'secondary' breakthrough.

Moreover, what might be called traditional Chinese religion and the philosophy termed Legalism, which was arguably more popular than Confucianism in the mid- 
first millennium BCE, each contained many elements antithetical to key conjectures of axiality. These elements persisted well into the Han period and beyond. Likewise, some of the axial transformations ascribed to Confucianism were actually present in Chinese ideologies long before the time of Confucius himself. Notably, there was a very strong moralizing element in early Chinese religious ideology that sought to regulate the 'proper' behavior of rulers, elites, and commoners alike. Specifically, much of the ritual activity undertaken by Kings during the Shang dynasty (ca. 1250$1050 \mathrm{BCE}$ ) was directed at divining the will of ancestor spirits and the great $\mathrm{Di}$, the chief deity of traditional Chinese religion, in order to adjust to these divine moral standards, while subordinate regional rulers, officials, and the general populace owed both legal and moral obligations to their superiors (Keightley 1999, Keightley 2004). Confucian thought did much to clarify and stabilize many of these earlier attitudes, but again it is difficult to assign to Confucius the accomplishment of having originated a clear moralizing ideology.

Moreover, the chief deity of Chinese traditional religion, Di, although powerful and perhaps omnipresent, was not quite omniscient (proxy 4). It is also probable that moralistic punishment (proxy 1), though clearly a strong element of Chinese religious ideology from early on, was left to the will of the gods/spirits and was not a major concern of religious agents in this life, including rulers or religious elite (Shahar and Weller 1996; ter Haar 2017 pers. comm.). This questions the institutionalization of this moralizing trait until at least the Han Empire, again raising the question of what caused this institutionalization to be so delayed in China where it was occurred much earlier in other 'axial' regions. Interestingly too, the idea of the ruler as a divine being (proxy 5) originates only in the third century BCE with the first ruler of the Qin Empire which preceded the Han, Emperor Shi Huangdi (Lewis 1999); quite the opposite of what would be expected from a rapidly 'axializing' area.

Further complicating the picture of China as a typical axial case is that the dominant polities in the region (mainly in the North) featured very well-articulated laws and proto-bureaucratic regimes from early on, at least by the late second millennium BCE under the well-famed Shang Dynasty (proxies 8, 11); however, the law was not widely and systematically applied to all again until the Qin and Han Empires, while neither the Shang nor subsequent polities (extending through most of the imperial period, which ended only in the 20th century $\mathrm{CE}$ ) placed serious constraints on rulers' authority (proxies 9-10, 12). China, then, offers another instance where the key measures of axiality are split, suggesting either that not all of the features traditionally discussed by scholars as markers of axiality really belong to the period, or that it is misleading to combine them together and that we should instead break them apart to look for which developments seem to come first and, thus, may have caused the others. We consider this further in the discussion section, below.

\section{Part 2. Analytical summaries for five allegedly non-axial regions}

1. EGPYT Egypt sits in Africa, outside of the core swath of territory in Eurasia associated with Axial transformations, though, as several commentators have pointed out, it shares many similarities to the five conventional Axial cases (Assmann 2008). We mention Egypt above due to the strong presence of Egyptian polities in Greece and the Levant during the second millennium BCE. The religious and philosophical traditions of 
Egypt remained remarkably consistent throughout the long history of Pharaonic rule, essentially from the mid-fourth millennium to the Roman conquest in $30 \mathrm{BCE}$ (Baines 1995, Mikalson 2006). This ideology was heavily concerned with preserving the cosmological order (ma'at), a concept with a clear moral dimension (proxy 2) tied with ideas of justice and fairness and ideals of prosociality (proxy 3 ) at least from the Old Kingdom period (end of the third millennium BCE), if not already present in predynastic times (Anđelković 2011, Baines 2017 pers. comm., Kemp 1983). Egyptian gods were generally conceived of as having all-knowledge; perhaps not quite omniscient a technical sense, but knowing enough to pass judgment in the afterlife and, perhaps, in this life should ma'at be disturbed (proxies 1,4) (Faulkner et al. 2008, Kemp 1983:140). A relatively strong ideal towards egalitarianism was also present from early on, though rulers, as god-Kings, were represented as clearly superior to others (proxies 5-7) (Baines 1995). Likewise, Egypt had very welldeveloped legal and administrative institutions (proxies 8-9,11) already in the third millennium BCE, though scholars are divided as to how much Pharaohs' actions were constrained by these institutional features in different periods (proxies 10,12).

The presence of so many typically 'axial' traits in Egyptian ideology centuries before the supposed Axial Age undermines the rather tight 'age' assigned by Jaspers and followers of 800-200 BCE. Importantly, the axial traits that were not present in preaxial Egypt — notably the secularization of rulers' authority and legitimacyremained absent in main-stream Egyptian ideology through the Axial period. This again raises questions about the correlation of the various factors proposed to typify axiality. It also begs the question of whether Egypt experienced an axial transformation, just earlier than most definitions of the period's temporal bounds, as many have argued (cf. Assmann 2008), or if the region only saw axiality after the 'secondary breakthrough' beginning with Islamic control in the late first millennium CE? Or if we ought, rather, to talk of the different traits separately and examine their individual dynamics; though in this case, the question becomes which developments caused the others?

2. TURKEY Turkey, the region known as Anatolia in antiquity, similarly offers evidence for the appearance of moralizing norms (proxy 2) tied to divine sanction and enforcement perhaps as early as the mid-second millennium BCE in the early Hittite Kingdom (Collins 2007). It has also been suggested that early Hittite rulers were not seen as god-kings (proxy 5) (compared to, for instance, Egyptian Pharaohs), though they were legitimated by and closely tied to concepts of supernatural beings (Hoffner 2006). Certainly, some elements of Bronze Age Anatolian life match the typical characterization of pre-axial, archaic societies. Notably, clear and strict enforcement of inequalities between different social groups including an emphasis on obedience to the near-unchallenged authority of rulers (proxies 3, 6-7, 10) (Bryce 2002, Collins 2007). Changes in the substance of the dominant ideologies in the region during the Axial Age period, though, are complicated by the growing power of the Achaemenid Persian Empire in Anatolia during this time and the Zoroastrian ideals they brought with them. It is, thus, difficult to assess Anatolia's dynamics, but analysis of the region certainly does not offer unambiguous support for its exclusion in discussions on the Axial Age.

The cases of Egypt and Turkey clearly contradict the notion that axiality was not experienced outside the handful of 'Axial' regions before the mid-first millennium BCE. Unfortunately, there is a dearth of reliable evidence for the precise contents of 
the religious and philosophical traditions present in many areas outside of the 'Old World' civilizations in the east Mediterranean, Near East, India, and China before the first millennium BCE. This makes it difficult to assess the presence of axial type traits in these regions prior to the Axial Age. Evidence from both East and West Eurasia from the mid-first millennium BCE and afterwards, however, is available.

3. JAPAN

Japan, interestingly, retained many non-Axial elements through at least the first millennium CE, in spite of a very lengthy history of occupation (though by relatively loose groups, in contrast to the more complex states seen in other parts of AfroEurasia during the Bronze and Iron Ages) . For instance, there is clear and lingering ideological assertion of the divinity of rulers along with reinforcement of social hierarchies (proxies 5-7), despite the spread of a moralizing and egalitarian ethic in both Shinto and Buddhist thought (Barnes 2009, Picken 2010, Takaeshi 1993). Observing this, in fact, led Eisenstadt (1996), a prominent Axial Age proponent, to conclude that Japan remained 'pre-Axial' through most of its history, even though Buddhist ideology and some Confucian ideals became popular in the region by the sixth century CE (Eisenstadt 1996). Some typically Axial traits did, however, appear starting in the mid-first millennium CE, co-occurring with the spread of Buddhism in the region, such as clear moralizing norms, prosocial activity and some egalitarian ideals (though not fully realized in practice), along with a regularization and formalization of law and administration (proxies 2-3, 8-9, 11) (Picken 2010, Takaeshi 1993). This complex picture accentuates the importance of breaking apart the different specific traits associated with axiality into individual proxies, as we do here. The key questions, then, are why did Japan attain some of the key Axial traits with the rise and spread of Buddhist ideology, but not others? More significantly, why was Buddhism sufficient to 'generate' axiality in India and facilitate it in China (as all proponents of the Axial Age attest), but not do so in Japan? Whatever the answers, this all indicates that something beyond the contents and adherence to Buddhist ideology in a given region is driving the spread of these Axial traits.

4. CAMBODIA Cambodia likewise offers very little reliable evidence concerning the first millennium $\mathrm{BCE}$ or earlier. The adoption and spread of Buddhist thought from the Angkor period in the early second millennium CE is associated with more pervasive moralizing norms and egalitarian ideals along with support for prosocial activity in Cambodia (proxies 2-3, 6-7), though Angkor Kings were still conceived of as divine rulers throughout this period (proxy 5). Critically, a pervasive ideology stressing moral behaviour was already present in the region in the Hindu doctrine and ritual activity, at least from the Funan period in the early fifth century CE (Higham 2014, Vickery 1986). While Buddhism was known in the region under the Funan Kingdom, this ideology did not become widespread or the central state ideology in the region until the beginning of the eleventh century CE, well into the Angkor period and, notably, long after both the traditional Axial Age and even later than the secondary breakthroughs (Harris 2008). The axial-type transformations that Cambodia did experience, then, cannot be shown clearly to have resulted from the spread of Buddhist thought from India and China; the timing simple does not line up. Instead, it developed these traits in a unique way, not in isolation from external influences, but also not from the diffusion of a seminal Axial religion. 
Italy tells a similar story to Cambodia. Due to the paucity of evidence for Bronze Age religious and philosophical ideology, it is difficult to reconstruct the pre-axial history of the proxies being explored here. By the mid-first millennium BCE, however, during the period of Roman Republican control over most of the peninsula, many of the key axial traits were present. Like Greece, though, it is difficult to draw any clear connection between these traits and a specific axial-type ideology. Traditional polytheistic Roman religion and ritual practice had a clear moralizing element, at least in orthopraxy, and a strong reinforcement of prosocial activity, and a secular basis of rulers' authority (proxies 2-3, 5) throughout the Republican period, before the widespread 'adoption' of an axial ideology — namely, Greek philosophy (neo-Platonic thought, Stoicism, Epicureanism) - by many Roman elites (Beard, North and Price 1998, Cornell and Lomas 2003, Orlin 2007). Conversely, many of the key Axial traits relating to the punishment of transgressions on moral grounds by all-knowing divinities (proxy 1,4) and egalitarian ideals (proxies 6-7) were not features of Roman society until well into the Christian period during Late Antiquity, despite the popularity in the Republican and Imperial periods of, for instance, Epicureanism and its egalitarian ideals (Uhalde 2012).

From the earliest periods of the Republic, and even in the pre-Republican period when Latium was under Etruscan rule, the region witnessed well-developed formalized institutions that help guide and regulate the behaviour of elites and their relationship to the non-elite populations. Interestingly, Rome did not develop a real professional bureaucracy (proxy 11) until the very end of the imperial period in the mid-first millennium CE, in spite of having such a long pedigree of well-established legal and administrative systems. It also worth noting that rulers during the Republican period were clearly constrained by both institutional regulations as well as moral/ideological norms, though these constraints only waned over the course of the first millennium BCE with the consolidation of authority by individual Emperors. Rome's Emperors were still constrained to some degree by law and precedent. Crucially, however, Emperors without question had far greater autocracy than Republican-era leaders, plus the ideological force of constraints weakened with increasing integration with the societies of the eastern Mediterranean, despite these societies having ostensibly given rise to some of the most impactful axial transformations. Like Japan, then, Italy presents a mixed bag in terms of the adoption and spread of the key, diagnostically Axial traits; and like in Cambodia, those traits it does exhibit can hardly be tied directly to a typical Axial ideology.

Lastly, as was the case with the relatively egalitarian ideologies of the Axial regions, any universalizing claims in the non-Axial regions explored in this section generally were not extended to women. Admittedly, Egypt and Japan are well-known for promoting relatively equitable treatment of women, who could serve as priests in both societies and seem to have been allowed to own property in their own names in Egypt from an early period. In both cases, however, these benefits a) did not result in equality with men, who still enjoyed exclusive social and legal privileges, and b) were present from pre-axial periods (Picken 2010, Wilfong 2010). In Cambodia and Italy, conversely, women were not accorded anything approaching equal rights in the periods under investigation here (Finley 2002, Miksic 2007:413, Whaling 2009). 